University of Nebraska - Lincoln

DigitalCommons@University of Nebraska - Lincoln

\title{
Dynamics of Plant Root Growth Under Increased Atmospheric Carbon Dioxide
}

\author{
M. Madhu \\ Central Soil and Water Conservation Research and Training Institute \\ J. L. Hatfield \\ USDA-ARS, jerry.hatfield@ars.usda.gov
}

Follow this and additional works at: https://digitalcommons.unl.edu/usdaarsfacpub

Madhu, M. and Hatfield, J. L., "Dynamics of Plant Root Growth Under Increased Atmospheric Carbon Dioxide" (2013). Publications from USDA-ARS / UNL Faculty. 1352.

https://digitalcommons.unl.edu/usdaarsfacpub/1352

This Article is brought to you for free and open access by the U.S. Department of Agriculture: Agricultural Research Service, Lincoln, Nebraska at DigitalCommons@University of Nebraska - Lincoln. It has been accepted for inclusion in Publications from USDA-ARS / UNL Faculty by an authorized administrator of DigitalCommons@University of Nebraska - Lincoln. 


\title{
Dynamics of Plant Root Growth under Increased Atmospheric Carbon Dioxide
}

\author{
M. Madhu and J. L. Hatfield*
}

\begin{abstract}
Plant growth is influenced by above- and belowground environmental conditions and increasing atmospheric carbon dioxide $\left(\mathrm{CO}_{2}\right)$ concentrations enhances growt hand yield of most agricultural crops. This review covers current knowledge on the impact of increasing $\mathrm{CO}_{2}$ concentration on root dynamics of plants in terms of growth, root/shoot (R/S) ratio, root biomass, root length, root longevity, root mortality, root distribution, root branching, root quality, and the response of these root parameters to management practices including soil water and nutrients. The effects of $\mathrm{CO}_{2}$ concentration on $\mathrm{R} / \mathrm{S}$ ratio are contradictory due to complexity in accurate underground biomass estimation under diverse crops and conditions. Roots become more numerous, longer, thicker, and faster growing in crops exposed to high $\mathrm{CO}_{2}$ with increased root length in many plant species. Branching and extension of roots under elevated $\mathrm{CO}_{2}$ may lead to altered root architecture and ability of roots to acquire water and nutrients from the soil profile with exploration of the soil volume. Root turnover is important to the global C budget as well as to nutrient cycling in ecosystems and individual plants. Agricultural management practices have a greater impact on root growth than rising atmospheric $\mathrm{CO}_{2}$ since management practices influence soil physical, chemical, and biological properties of soil, consequently affects root growth dynamics in the belowground. Less understood are the interactive effects of elevated $\mathrm{CO}_{2}$ and management practices including drought on root dynamics, fine-root production, and water-nutrient use efficiency, and the contribution of these processes to plant growth in water and nutrients limited environments.
\end{abstract}

G LOBAL CLIMATE CHANGE has emerged as an important environmental challenge due to its potential impact on biological systems on Earth. Atmospheric concentrations of $\mathrm{CO}_{2}$ have steadily increased from approximately $315 \mu \mathrm{mol} \mathrm{mol}^{-1}$ in 1959 to a current atmospheric concentration of approximately $385 \mu \mathrm{mol} \mathrm{mol}{ }^{-1}$ which converts to an average annual increase rate of nearly $2 \mu \mathrm{mol} \mathrm{mol}{ }^{-1}$ (Keeling and Whorf, 2005). At this rate of increase, concentrations are projected to reach levels between 500 and $1000 \mu \mathrm{mol} \mathrm{mol}^{-1}$ by 2100 (IPCC, 2007). Carbon dioxide is not only a major greenhouse gas, but essential to plant growth (Kramer, 1981; Dahlman et al., 1985; Warrick, 1988; Kimball, 2011). The flow of C from photosynthesizing tissues of higher plants, through the roots and into the soil is one of the key processes in terrestrial ecosystems. Increases in atmospheric $\mathrm{CO}_{2}$ concentration will have direct and indirect effects on crop plants and increases in $\mathrm{CO}_{2}$ will generally increase plant productivity and water-use efficiency (Drake and Gonzàlez-Meier, 1997; IPCC, 2007). The long-term response to $\mathrm{CO}_{2}$ remains uncertain and will depend on environmental constraints. Yields of most agricultural crops will increase under elevated $\mathrm{CO}_{2}$ with productivity increases in the range 15 to $41 \%$ for $\mathrm{C}_{3}$ crops and 5 to $10 \%$ for

M. Madhu, Central Soil and Water Conservation Research and Training Institute, Research Centre, Sunabeda, Koraput, Odisha-763 002, India; J.L. Hatfield, Agriculture and the Environment (NLAE), USDA-ARS, Ames, IA 50011. Received 16 Jan. 2013. *Corresponding author (jerry.hatfield@ars. usda.gov)

Published in Agron. J. 105:657-669 (2013)

doi:10.2134/agronj2013.0018

Copyright (c) 2013 by the American Society of Agronomy, 5585 Guilford Road, Madison, WI 53711. All rights reserved. No part of this periodical may be reproduced or transmitted in any form or by any means, electronic or mechanical, including photocopying, recording, or any information storage and retrieval system, without permission in writing from the publisher.
$\mathrm{C}_{4}$ crops (Cure, 1985; Kimball, 1983; IPCC, 2007; LotzeCampen and Schellnhuber, 2009).

Analyses of plant responses to elevated atmospheric $\mathrm{CO}_{2}$ have focused largely on aboveground processes; however, understanding the effects on photosynthesis are insufficient to answer questions about overall plant response to a changing atmosphere. A whole-plant perspective is required to understand the critical feedbacks and adjustments occurring within a plant and between plants and soil. An overlooked and under studied aspect of plant response to rising $\mathrm{CO}_{2}$ is on belowground processes. The vital role of roots as an interface between the lithosphere and biosphere is necessary to understand plant response to elevated $\mathrm{CO}_{2}$. Despite the important role roots play, they have been an understudied component of agricultural research since they exist underground. Root health in crop plants will play a major role in providing sustainable highly productive crops with the ability to cope with climate changes; however, the effect of increasing $\mathrm{CO}_{2}$ on root growth and development is poorly understood. Climate change is expected to increase the incidence of extreme weather events, such as drought, heat waves, and heavy precipitation and floods, causing crop production to become more variable (IPCC, 2001, 2007; Hatfield et al., 2011). Under these conditions, many of the environmental factors, for example, water, temperature, light, nutrition, salinity, air pollutants, and competition have significant interactions with $\mathrm{CO}_{2}$ concentration on root responses for numerous species as summarized by Rogers et al. (1994). Understanding of dynamics of crop roots is important from the point of view of management of available resources to increase the productivity of crops and resilience of crops to climate stress.

Abbreviations: ABA, abscisic acid; FACE, free air carbon dioxide enrichment; $\mathrm{R} / \mathrm{S}$, root/shoot ratio. 
The objectives of this review are to express the importance of understanding the dynamic of crop species and to summarize the current knowledge on the effect of increasing $\mathrm{CO}_{2}$ concentration on root growth, $\mathrm{R} / \mathrm{S}$ ratio, root biomass, root length, root longevity, root mortality, root distribution, root branching, root quality, and the response of these root parameters to soil management practices, and interactions with soil water and nutrient status.

\section{Root Biomass}

Increasing atmospheric $\mathrm{CO}_{2}$ significantly increased the final plant biomass, aboveground biomass, leaf area and belowground biomass (Obrist and Arnone, 2003). Increased root growth contributes to root biomass and root dry weight under elevated atmospheric $\mathrm{CO}_{2}$ regardless of species or study conditions (Rogers et al., 1994, 1996). Roots often exhibit the greatest relative dry weight gain among plant organs (Imai and Murata, 1976; Wittwer, 1978; Rogers et al., 1983; Imai et al., 1985; Hocking and Meyer, 1991; Norby et al., 1992), even more than aboveground biomass or leaf area production (Norby, 1994; Rogers et al., 1999; Pritchard and Rogers, 2000; Bernacchi et al., 2000). However, increased allocation of $\mathrm{C}$ to plant-root systems in response to $\mathrm{CO}_{2}$ levels may offset losses from increased activity of soil microorganisms (Suter et al., 2002). Increases in root mass may benefit mycorrhizal fungi and production of glomalin, a glycoprotein produced by endomycorrhizae contributing to soil aggregation (Rillig et al., 1999).

Wheat (Triticum aestivum L.) (Chaudhuri et al., 1990; McMaster et al., 1999, Wechsung et al., 1995), sorghum [Sorghum bicolor (L.) Moench](Chaudhuri et al., 1986), Black gram (Vigna mungo var. mungo; Vanaja et al., 2007), and soybean [Glycine max (L.) Merr.] (Del Castillo et al., 1989; Rogers et al., 1992), have shown increases in root dry weight under $\mathrm{CO}_{2}$ enrichment (Rogers et al., 1994). Laboratory studies on cotton (Gossypium hirsutum L.) plants in a free air carbon dioxide enrichment (FACE) project revealed dry weights, lengths, and volumes of taproots, lateral roots, and fine roots were higher for $\mathrm{CO}_{2}$-enriched cotton plants with a short-term exposure to increased $\mathrm{CO}_{2}$ for $6 \mathrm{wk}$ (Prior, 1992; Prior et al., 1994a, 1994b; Rogers et al., 1993). Observations from a spring wheat FACE study revealed a $37 \%$ increase in total root dry mass in the $\mathrm{CO}_{2}$-enriched plot during early vegetative growth (stem elongation) and sustained root growth rates until anthesis (Wechsung et al., 1999). The combined effect of temperature and elevated $\mathrm{CO}_{2}$ concentration affect growth and development of roots, Pilumwong et al. (2007) observed in groundnut (Arachis hypogaea L.) that fibrous root dry weight increased with increased $\mathrm{CO}_{2}$ when plants were grown at $25 / 15^{\circ} \mathrm{C}$, but decreased with increasing $\mathrm{CO}_{2}$ at $35 / 25^{\circ} \mathrm{C}$. At $35 / 25^{\circ} \mathrm{C}$, there was greater root dry weight by $34 \%$ at $400,14 \%$ at 600 , and $7 \%$ at $800 \mu \mathrm{mol} \mathrm{mol}{ }^{-1}$ compared with $25 / 15^{\circ} \mathrm{C}$.

Narrow leaf plantain (Plantago lanceolata) seedlings grown under elevated $\mathrm{CO}_{2}\left(800 \mu \mathrm{mol} \mathrm{mol}{ }^{-1}\right)$ produced $180 \%$ greater root dry matter than at $400 \mu \mathrm{mol} \mathrm{mol}{ }^{-1}$ and amount of plant $\mathrm{C}$ recovered was 3.2 times greater from the elevated $\mathrm{CO}_{2}$ treatment (Hodge and Millard,1998). The same response was found for raspberry (Rubus idaeus L.) plantlets (Laforge et al., 1991). A meta-analysis of the effects of elevated $\mathrm{CO}_{2}$ on woody plant species (Curtis and Wang, 1998) found biomass responses were strongly affected by environmental stress factors and to a lesser degree by duration of $\mathrm{CO}_{2}$ exposure. They reported belowground biomass responses to $\mathrm{CO}_{2}$ were highly significant overall $(+38 \%, \mathrm{k}=64)$ but were affected by stress and length of exposure to increased $\mathrm{CO}_{2}$. About 36 studies reported underground biomass under unstressed trees increased by $41.5 \%$ under elevated $\mathrm{CO}_{2}$. Some plant species namely, kidney vetch (Anthyllis vulneraria), hoary plantain (Plantago media) (Ferris and Taylor, 1993), spartina with shallow rooting depth (Curtis et al., 1990), and common bean (Phaseolus vulgaris L.) (Salsman et al., 1999) exhibited no response of root dry matter production to elevated $\mathrm{CO}_{2}$.

Root growth of crop plants is often stimulated to a greater extent than other plant parts to increased $\mathrm{CO}_{2}$ concentration (Rogers et al., 1994; Norby et al., 1992; Kimball et al., 2002; Pritchard and Amthor, 2005; Heinemann et al., 2006; Vanaja et al., 2007). Hodge and Millard (1998) observed belowground growth was stimulated in narrow leaf plantain seedlings with increased $\mathrm{CO}_{2}$ concentration than aboveground components. In maize (Zea mays L.) grown under elevated $\mathrm{CO}_{2}$ relative growth rate of maize roots was increased compared to the relative shoot growth rate (Whipps, 1985) because of increased C translocation to the roots. Pilumwong et al. (2007) reported increased root growth of groundnut due to increasing $\mathrm{CO}_{2}$ concentration. With no limitations to water and nutrients, elevated $\mathrm{CO}_{2}$ increased root and shoot growth of most plant species including tree species (Obrist and Arnone, 2003; Rogers et al., 1996; Pregitzer et al.,1995) but the response varied among species (Hanley et al., 2004). Salsman et al. (1999) found increased $\mathrm{CO}_{2}$ affected root and shoot growth of Phaseolus acutifolius but not $P$. vulgaris due to increased concentration of starch in roots of $P$. acutifolius by 10 -fold, while root concentrations of abscisic acid (ABA) doubled and caused more $\mathrm{C}$ to be allocated to root growth. Several laboratory studies have reported that roots have the capacity to produce significant amounts of ABA (Walton et al., 1976; Cornish and Zeevaart, 1985; Zhang and Davies, 1987) but applications of ABA have been shown to both increase (Mulkey et al., 1983; Pilet and Saugy, 1987) and decrease root growth (Watts et al., 1981; Jones et al., 1987).

Growth and morphology of four native chalk grassland herbs roots responded differently to increasing $\mathrm{CO}_{2}$ (Ferris and Taylor, 1993). Root growth and biomass was stimulated by elevated $\mathrm{CO}_{2}$ for Sanguisorba minor and Lotus corniculatus with no significant effect on growth and root biomass for $A$. vulneraria or $P$. media. They suggested these growth and root responses could potentially lead to changes in the structure of this plant community with continued increases in $\mathrm{CO}_{2}$. Increasing $\mathrm{CO}_{2}$ in greenhouse environments increased the percentage of cuttings which formed roots in a range of ornamental and floricultural species (Lin and Molnar, 1981; French and Alsbury, 1989), including raspberry plantlets (Laforge et al., 1991).

Agricultural management practices may have a greater impact on root growth and soil $\mathrm{C}$ storage than rising atmospheric $\mathrm{CO}_{2}$ (Canadell et al., 1996b; Paustian et al., 1996) because tillage systems influence soil temperature (Dwyer et al., 1995), mechanical resistance (Cox et al., 1990), macropore continuity (Roseberg and McCoy, 1992), and available soil water (Cox et al., 1990) through the effects on rooting depth and root distribution with depth. Rooting depth varies with 
season, soil texture, and tillage, and increased rooting depth is associated with increased tillage and decreased soil moisture in surface soil layers (Dwyer et al., 1996). Soil water content in the upper soil layers is confounded by reduced soil water holding capacity and thus plant growth and root development depends on rainfall distribution (Lampurlanés et al., 2001).

At the present time, the interactions of $\mathrm{CO}_{2}$ enrichment and agricultural management practices on plant root growth are not well understood (Swinnen et al., 1995; van Noordwijk et al., 1994). Although a substantial quantity of data indicates that root spatial distributions are significantly affected by tillage practices, it remains unclear whether temporal or spatial distribution of roots differs among conventional compared with conservation tillage systems. Swinnen et al. (1995) found that decay and turnover in barley (Hordeum vulgare L.) roots were higher in conventional agricultural systems than in a production system characterized by reductions in nutrient input, soil tillage, and use of biocides, but were not different in wheat under the same management scenarios. In another study, sugar beet (Beta vulgaris L.) grown with minimum tillage had lower fine-root production than in the conventional cropping system, whereas fine-root production of wheat was unchanged (van Noordwijk et al., 1994).

Prior et al. (2005) studied the effects of management and $\mathrm{CO}_{2}$ on aboveground biomass production with an emphasis on changes in soil $\mathrm{C}$ storage. They found a substantial increase in soil $\mathrm{C}$ concentration at the 0 - to 5 - $\mathrm{cm}$ depth increment in the conservation system compared to the conventional system, and in the $\mathrm{CO}_{2}$-enriched compared to ambient plots, after two cropping cycles (4 yr). Pritchard et al. (2006) concluded that $\mathrm{CO}_{2}$ enrichment enhanced cumulative seasonal root length production $(+58 \%)$ and mortality $(+59 \%)$ in conventionally managed sorghum, but had no effect in plots with conservation systems. Sorghum under $\mathrm{CO}_{2}$ enrichment produced more roots at shallow soil depths compared to ambient plots and this additional root production occurred early in the growing season. Conventionally managed sorghum produced less root length in the top few centimeters of soil compared to conservation plots due to increased soil water availability in the conservation tillage plots. Seasonal root length mortality and production were higher at the shallower soil depths in the conservation plots than in the conventional plots. Increases in root mortality in $\mathrm{CO}_{2}$-enriched plots were proportional to production increases and no effect on root longevity which associated with depth in the soil profile (Pritchard et al., 2006). This was probably caused by the effects of tillage on soil water content due the presence of surface residues coupled with no-till management enhance soil moisture absorption and retention compared to conventional tillage with no residue (Newell and Wilhelm, 1987).

A particular limitation to understanding root dynamics is that most studies do not include measurements below a meter (Nepstad et al., 1994; Batjes, 1996; Canadell et al., 1996b; Jobbagy and Jackson, 2000; Guo and Gifford, 2002; Schenk and Jackson, 2002a, 2002b; Robinson, 2004; Bradley et al., 2005; Lorenz and Lal, 2005; Mokany et al., 2006; Qin and Huang, 2010; Wang et al., 2010). Baker et al. (2007) argued depth of root sampling confounded understanding the impact of tillage and management factors on root growth, root turnover, distribution, etc. and sequestration of $\mathrm{C}$ at different depths in the soil.
Roots of drought-stressed plants grown with elevated $\mathrm{CO}_{2}$ produced significantly higher root dry mass than roots of wellwatered plants grown with ambient $\mathrm{CO}_{2}$ (Chaudhuri et al., 1990). These responses in root growth and morphology led to elevated $\mathrm{CO}_{2}$ and reduced soil water supports the hypothesis that plants grown in a high $\mathrm{CO}_{2}$ environment may better compensate to soil-water-stress conditions (Wechsung et al., 1999; Schenk and Jackson, 2002b). An adoption mechanism of plants to water stress condition occurs by physiological and biochemical changes in the plant. Eggplant (Solanum melongena L.) roots showed low hydraulic conductance at repetitive stress due to synthesis and accumulation of suberin in the root cells under elevated $\mathrm{CO}_{2}$ and this change in root structure may occur from synthesizing suberin lipids in endo- and exo-dermis layers regardless of soil water availability or stress intensity. Lowering conductance is highly desirable for agricultural plants when water supply is limited in the growth and development stage (Sarker and Hara, 2009). These observations suggest increasing $\mathrm{CO}_{2}$ concentration in the global atmosphere might be beneficial for using soil water by minimizing transpiration loss and lowering hydraulic conductance under higher $\mathrm{CO}_{2}$. In a comprehensive review of FACE experiments on agricultural crops, Kimball (2011) and Kimball et al. (2002) determined that for a $300 \mu \mathrm{mol} \mathrm{mol}{ }^{-1}$ increase in atmospheric $\mathrm{CO}_{2}$ concentration, the root biomass of wheat, ryegrass (Lolium multiflorum Lam.), and rice (Oryza sativa L.) increased 70\% with ample water and N, 58\% at low N, and 34\% at low water, while clover experienced a $38 \%$ increase at ample water and $\mathrm{N}$, plus a $32 \%$ increase at low $\mathrm{N}$. The changes were greatest in cotton with a $96 \%$ increase in root biomass at ample water and $\mathrm{N}$. Another FACE study on cotton and sorghum in monoculture and two plant densities under dry and wet soil water condition was conducted by Derner et al. (2003) and showed total root biomass in the upper $1.2 \mathrm{~m}$ of the soil was not influenced by $\mathrm{CO}_{2}$ or soil moisture in monoculture or in mixture; however, under dry conditions there were significantly more roots at soil depths below $45 \mathrm{~cm}$. Sorghum roots comprised 81 to $85 \%$ of the total roots in the low density mixture and 58 to $73 \%$ in the high density mixture. Carbon dioxide enrichment partly offsets the negative effects of interspecific competition on cotton in both low and high density mixture by increasing aboveground biomass (Derner et al., 2003). The interacting effects of $\mathrm{CO}_{2}$ and watering frequency on wheat root growth and nutrient uptake pattern increased water use per plant 1 to 25 times at 350 than at $700 \mu \mathrm{mol} \mathrm{mol}{ }^{-1} \mathrm{CO}_{2}$ and 1 to 4 times in the "wet" compared to the "dry" treatment (Van Vuuren et al., 1997). Root biomass increased with $\mathrm{CO}_{2}$ and with watering frequency. Nutrient uptake was affected and there were interactions with water availability but interactions were different for $\mathrm{N}, \mathrm{K}$, and $\mathrm{P}$, due to differences in nutrient availability and mobility in the soil (Van Vuuren et al., 1997).

Root growth is positively affected by increases in $\mathrm{CO}_{2}$ concentration across almost all species and is often stimulated more than shoot biomass. There is no simple assessment of the interacting effects of soil physical conditions and nutrient availability and the interaction with increasing $\mathrm{CO}_{2}$ on root and shoot growth. A summary of the combined effects of increased $\mathrm{CO}_{2}$ for the different root parameters is shown in Table 1. 
Table I. Overall effects of increased $\mathrm{CO}_{2}$ on various root parameters.

\begin{tabular}{|c|c|c|c|}
\hline Root parameter & Species & Type of $\mathrm{CO}_{2}$ enrichment & Overall effect \\
\hline $\begin{array}{l}\text { Root biomass/ } \\
\text { growth }\end{array}$ & $\begin{array}{l}\text { Agricultural plants, groundnut, } \\
\text { grassland herbs }\end{array}$ & $\begin{array}{c}\text { Laboratory studies, greenhouse } \\
\text { studies }\end{array}$ & $\begin{array}{l}\text { Increase in root growth was larger than shoot } \\
\text { growth and root biomass increased as part of } \\
\text { overall growth response to increased } \mathrm{CO}_{2} \text {. }\end{array}$ \\
\hline \multirow[t]{2}{*}{$\begin{array}{l}\text { Root/shoot }(R / S) \\
\text { ratio }\end{array}$} & $\begin{array}{l}\text { Agricultural plants, groundnut, } \\
\text { grassland herbs, forest species }\end{array}$ & $\begin{array}{l}\text { Laboratory, greenhouse, } \\
\text { controlled chamber studies }\end{array}$ & $\begin{array}{c}\text { Results vary among studies; however, } 60 \% \text { of } \\
\text { studies show a positive response on R/S, } 37 \% \\
\text { show a negative response, and } 3 \% \text { show no } \\
\text { response (Rogers et al., 1996). }\end{array}$ \\
\hline & & & $\begin{array}{l}\text { Under limited soil water or nutrient availability, } \\
\text { responses to increased } \mathrm{CO}_{2} \text { are more variable. }\end{array}$ \\
\hline $\begin{array}{l}\text { Root length/ } \\
\text { rooting depth }\end{array}$ & $\begin{array}{l}\text { Agricultural plants, groundnut, } \\
\text { grassland herbs, forest species }\end{array}$ & $\begin{array}{l}\text { Laboratory, greenhouse, } \\
\text { controlled chamber studies }\end{array}$ & $\begin{array}{l}\text { Increased root length across species is the most } \\
\text { common response observed. Root branching also } \\
\text { increased with } \mathrm{CO}_{2} \text { enrichment (Rogers et al., 1994). }\end{array}$ \\
\hline Root branching & $\begin{array}{l}\text { Agricultural plants, } \\
\text { groundnut, grassland herbs, } \\
\text { horticultural species }\end{array}$ & $\begin{array}{l}\text { Laboratory, greenhouse, } \\
\text { controlled chamber studies, } \\
\text { free air carbon dioxide } \\
\text { enrichment (FACE) studies }\end{array}$ & $\begin{array}{l}\text { Increased root branching is commonly } \\
\text { observed in most species and more evident } \\
\text { in the upper soil profile. }\end{array}$ \\
\hline $\begin{array}{l}\text { Root thickness, } \\
\text { quality, diameter }\end{array}$ & $\begin{array}{l}\text { Agricultural plants, groundnut, } \\
\text { grassland herbs, horticultural } \\
\text { species, forests }\end{array}$ & $\begin{array}{l}\text { Laboratory, greenhouse, } \\
\text { controlled chamber studies }\end{array}$ & $\begin{array}{l}\text { Increased root thickness and diameter are most } \\
\text { commonly observed. Diameter changes are more } \\
\text { difficult to quantify. }\end{array}$ \\
\hline $\begin{array}{l}\text { Root mortality/ } \\
\text { root turnover }\end{array}$ & $\begin{array}{l}\text { Agricultural plants, } \\
\text { groundnut, grassland herbs, } \\
\text { horticultural species, forests }\end{array}$ & $\begin{array}{l}\text { Laboratory, greenhouse, } \\
\text { controlled chamber studies, } \\
\text { FACE studies }\end{array}$ & $\begin{array}{l}\text { Increases in root mortality and turnover rates } \\
\text { are observed across species with increased } \mathrm{CO}_{2} \text {. } \\
\text { There is an interaction with temperature, soil } \\
\text { moisture, and nutrient supply which confounds } \\
\text { observations on root turnover rates. }\end{array}$ \\
\hline
\end{tabular}

\section{Root/Shoot Ratio}

Exposure of plant canopies to high $\mathrm{CO}_{2}$ concentration often stimulates growth of shoots and roots, but the question remains whether elevated atmospheric $\mathrm{CO}_{2}$ concentration affects root and shoot growth proportionally (Rogers et al., 1996). The general consensus is that photosynthesis and $\mathrm{C}$ allocation to plant roots increases as atmospheric $\mathrm{CO}_{2}$ rises which leads to an increase in above and below biomass (Del Castillo et al., 1989; Norby et al., 1992; Rogers et al., 1994). Root/shoot ratio is the simple calculation of the ratio of root dry mass to shoot (or stem) dry mass and should serve as a measure of the preferential allocation of $\mathrm{C}$ to roots or shoots. Allen et al. (1988) reported that soybean grown under increased $\mathrm{CO}_{2}$ maintained a similar partitioning of $\mathrm{C}$ into their respective components. Similar results were reported by Baxter et al. (1994) in grasses, but roots often exhibit the greatest relative dry weight gain under high $\mathrm{CO}_{2}$ (Hocking and Meyer,1991; Imai and Murata,1976; Imai et al., 1985; Norby et al.,1992; Rogers et al.,1983). The partitioning pattern of photosynthates depends on plant development stage, plant species, and plant growth conditions along with physiological factors (Van Veen et al., 1991). Various studies have shown between 10 and $40 \%$ of the total net $C$ assimilation of crops was transferred to underground biomass in the form of roots, microbial and soil biomass, and respired $\mathrm{CO}_{2}$ and organic compounds (Barber and Martin, 1976; Whipps, 1984; Helal and Sauerbeck, 1986; Liljeroth et al., 1990; Keith et al.,1986).

Observations on $\mathrm{R} / \mathrm{S}$ response to $\mathrm{CO}_{2}$ are contradictory as evidenced by the wide range of results obtained from different studies. Oechel and Strain (1985) found root growth under increasing atmospheric $\mathrm{CO}_{2}$, plants allocated proportionately more $\mathrm{C}$ belowground, increasing $\mathrm{R} / \mathrm{S}$ ratios. The range of response in $\mathrm{R} / \mathrm{S}$ among crop plants to $\mathrm{CO}_{2}$ doubling ranged from a $8.5 \%$ decrease to a $6.4 \%$ increase, except in sweet potato [Ipomoea batatas (L.) Lam. var. batatas], in which a 34.9\% increase was observed (Cure, 1985). Results showed R/S was not significantly affected by higher $\mathrm{CO}_{2}$ concentration in Larrea tridentate, a desert herb (Obrist and Arnone, 2003), tall grasses (Mo et al., 1992), four native chalk grassland herbs (Ferris and Taylor, 1993), and winter wheat (Chaudhuri et al.,1990; Havelka et al., 1984). Many studies showed increased R/S (Rogers et al., 1983; Biswas and Hileman, 1985; Idso et al., 1988; Baker et al., 1990; Rogers et al., 1992; Ceulemans and Mousseau, 1994; Pritchard et al., 1999; Rogers et al., 1999), while other studies showed decreased R/S (Salsman et al.,1999; McMaster et al., 1999). In field studies, an increase in the proportion of total dry mass in tubers after exposure to increased $\mathrm{CO}_{2}$ was observed for sweet potato (Biswas and Hileman, 1985; Bhattacharya et al., 1990), carrot (Daucus carota L.), and radish (Raphanus sativus L.) (Idso et al., 1988). Idso et al. (1988) suggested that plants whose primary yield component is produced aboveground, atmospheric $\mathrm{CO}_{2}$ enrichment has a significant effect on $\mathrm{R} / \mathrm{S}$. Increases in $\mathrm{R} / \mathrm{S}$ occurred more frequently for agronomic crops, particularly root and tuber crops and natural community species Substantial $\mathrm{CO}_{2}$ research conducted with several forest tree species namely, shortleaf pine (Pinus echinata Mill.) (Norby et al., 1987; O’Neill et al., 1987b), virginia pine (P. virginiana Mill.) (Luxmoore et al., 1986), white oak (Quercus alba L.)(Norby et al. (1986a, 1986b; O'Neill et al., 1987b; Norby and O'Neill, 1989), yellow poplar (Liriodendron tulipifera L.) (O’Neill et al., 1987a; Norby et al., 1992), and N-fixing woody plants (Norby, 1987) have revealed an increased R/S, C allocation to roots, root exudation, nutrient uptake, and mycorrhizal colonization under elevated $\mathrm{CO}_{2}$.

Rogers et al. (1996) summarized a substantial variation in $\mathrm{R} / \mathrm{S}$ response in crop plants across a range of experimental conditions. He reported crops showed positive responses in R/S to elevated $\mathrm{CO}_{2}, 59.5 \%$ of 264 observations from 62 reports; negative responses appeared $37.5 \%$ of the studies and $3.0 \%$ of the studies showed no response (Table 1). There is no general consensus among researchers on the degree of positive response on $R / S$ of 
different species; however, these results are tempered by the interactions with water and nutrient management in the soil profile.

Under non-limiting conditions of water and nutrients for growth, dry matter partitioning to the root is moderately changed by $\mathrm{CO}_{2}$ enrichment. However, increases in $\mathrm{R} / \mathrm{S}$, frequently observed under limiting conditions of water and/ or nutrients, allows the plant to explore a greater soil volume and extract more water and nutrients (Stulen and den Hertog, 1993). Bazzaz (1990) stated that there would be an increase in $\mathrm{C}$ allocation to roots when nutrients and water were limiting. Biomass allocation models such as functional balance developed by Davidson (1969) and C/nutrient substrate ratio developed by Reynolds and Thornley (1982) predicted increases in tissue $\mathrm{C} / \mathrm{N}$ ratios as $\mathrm{N}$ becomes more limiting relative to $\mathrm{C}$ leading to increased biomass allocation to roots. Eamus and Jarvis (1989) summarized that under low nutrient conditions there would be an increase in $\mathrm{R} / \mathrm{S}$, and this conclusion was confirmed by Ceulemans and Mousseau (1994). There are confounding effects of increasing $\mathrm{CO}_{2}$ on root allocation and developmental rate and Norby (1994) observed a small (+6\%) increase in $\mathrm{R} / \mathrm{S}$ at high $\mathrm{CO}_{2}$, with no significant response under nutrient stress. McGuire et al. (1995) and Wullschleger et al. (1995) did not find a significant $\mathrm{CO}_{2}$ effect on biomass allocation between roots and shoots. The interactions between nutrient status and $\mathrm{CO}_{2}$ are not clearly defined because the conclusions by Norby et al. (1987) were that limiting nutrients may promote partitioning to the roots and assimilate partitioning under high $\mathrm{CO}_{2}$ may depend on nutrient status (Lawlor and Mitchell, 1991) and requires that we quantify the nutrient levels in the soil when interpreting $\mathrm{R} / \mathrm{S}$ responses.

The direct effect of increasing $\mathrm{CO}_{2}$ on $\mathrm{R} / \mathrm{S}$ has no clearly defined conclusion (Stulen and den Hertog, 1993; Rogers et al.,1994). The underlying assumption that a larger proportion of dry matter produced under $\mathrm{CO}_{2}$ enrichment is preferentially allocated to roots and increased under limiting water and nutrient supply needs to be evaluated. Differences among experiments can be attributed to crop type, genotypes, resource supply (water and nutrients), and other experimental factors, that is, duration and method of exposure, and interacting treatment variables (Idso et al., 1988; Rogers et al., 1996). This is further complicated by poor estimate of $\mathrm{C}$ returned to the soil via the death of fine roots at harvest leading to an underestimation of $\mathrm{C}$ allocation (Stulen and den Hertog, 1993). Recent observations of in situ root dynamics from nondestructive monitoring methods reveals estimates of net belowground production significantly underestimates gross production (Fahey and Hughes, 1994; Hendrick and Pregitzer, 1992, 1993a, 1993b). Berntson and Bazzaz (1997a) argued that elevated $\mathrm{CO}_{2}$ increases the magnitude of cumulative gross production and cumulative gross root loss with a large seasonally dependence on these responses. Elevated $\mathrm{CO}_{2}$ enhances gross production of roots early in the growing season, before maximum root length and enhance cumulative gross loss of roots in the latter portion of the growing season after maximum root length had been achieved. They concluded that static assessments of belowground productivity may underestimate gross fine root productivity and turnover, and this bias may be exaggerated with elevated $\mathrm{CO}_{2}$. Stulen and den Hertog (1993) list several reasons why determination of $\mathrm{R} / \mathrm{S}$ is subject to experimental error; including problems in defining the R/S boundary, quantitative recovery of roots (especially fine roots), root decomposition, nutrient and water regime in the soil, ontogenetic effects, and accumulation of non-structural carbohydrates.

\section{Root Length and Rooting Depth}

When exposed to increased $\mathrm{CO}_{2}$, roots have been observed to become more numerous, longer, thicker, and faster growing in crops (Chaudhuri et al., 1990; Prior et al., 1994a, 1994b, 1995) with increased root length in many plant species (Norby, 1994; Rogers et al., 1999; Pritchard and Rogers, 2000; Bernacchi et al., 2000). Root distributions with depth of sorghum with elevated $\mathrm{CO}_{2}$ was studied by Pritchard et al. (2006) and they concluded the greatest root length was observed between 4 - and $15-\mathrm{cm}$ soil depths. At physiological maturity, a larger percentage of total root length had died at shallow soil depths compared to deeper depths; for example, $87 \%$ of roots produced at the shallow soil depths died before harvest compared to $48 \%$ at the lower depths. Daily production of new roots occurred primarily in the early part of the growing season and the maximum root length production per day occurred when mortality and production rates were nearly equivalent at approximately $59 \mathrm{~d}$ after planting.

Lengths and volumes of taproots, lateral roots and fine roots were higher for $\mathrm{CO}_{2}$-enriched cotton plants (Prior, 1992; Prior et al., 1994a, 1994b; Rogers et al., 1993). A 110\% increase in root length of soybean was observed as $\mathrm{CO}_{2}$ concentration increased from 350 to $700 \mu \mathrm{mol} \mathrm{mol}{ }^{-1}$ (Rogers et al., 1992). Increased root length and number was found in sweet potato (Bhattacharya et al., 1990), and in P. acutifolius and P. vulgaris (Salsman et al., 1999). Increased stele and cortex diameter, root diameter in the root hair zone, length of unbranched first order lateral roots, total root length, and root volume was increased in cotton with increased $\mathrm{CO}_{2}$ (Rogers et al., 1992).

Temperature and $\mathrm{CO}_{2}$ effects were studied in groundnut and total root length increased with increasing $\mathrm{CO}_{2}$ from 400 to $800 \mu \mathrm{mol} \mathrm{mol}^{-1}$ at both low and high temperatures (Pilumwong et al., 2007). Although the difference was not significant, there was an observed increase of $13 \%$ when plants were grown at $600 \mu \mathrm{mol} \mathrm{mol}^{-1} \mathrm{CO}_{2}$, and $20 \%$ at $800 \mu \mathrm{mol} \mathrm{mol}{ }^{-1} \mathrm{CO}_{2}$. However, visible root length, root number, and root length density increased with $\mathrm{CO}_{2}$ increases from 400 to $800 \mu \mathrm{mol} \mathrm{mol}^{-1}$ at $25 / 15^{\circ} \mathrm{C}$, but decreased as $\mathrm{CO}_{2}$ increased when temperatures increased to $35 / 25^{\circ} \mathrm{C}$ (maximum/minimum temperature). Root branching was the primary factor affecting total length and volume of roots. Berntson and Woodward (1992) concluded $\mathrm{CO}_{2}$ enrichment resulted in more branched and longer root system of Senecio vulgaris. Many studies have found elevated $\mathrm{CO}_{2}$ resulted in more and/or longer plant roots or faster root growth, possibly leading to increased penetration of the soil profile (Baker et al., 1990; Chaudhuri et al., 1990; Rogers et al., 1992) and/or horizontal spread of the roots (Idso and Kimball, 1991)

Root length and number have been the most frequently evaluated in horticultural species ( 45 and $74 \%$ of studies, respectively) compared with plants in other categories (2-12\%). A majority (61-100\%) of studies found that increased $\mathrm{CO}_{2}$ resulted in more and/or longer plant roots (Rogers et al., 1994) which led to increased depth (Baker et al., 1990; Rogers et al., 1992) and/or horizontal spread (Idso and Kimball, 1991, 1992) (Table 1).

Rooting depth has important implications for hydrology, biogeochemistry, and primary productivity of terrestrial 
ecosystems (Jackson et al., 1997) and since the depth of plant roots depends on a variety of conditions, including soil properties, vegetation type, nutrient availability, and climate there are a number of potential implications from rooting depth response to $\mathrm{CO}_{2}$ (Guswa, 2010). A number of papers and reviews describe the genetic control of root architecture and the variation between plant types and individual plant cultivars about the maximum rooting depth (Kell, 2011). Plant root depths vary greatly in similar soils for different organisms (e.g., Burch and Johns, 1978; Jackson et al., 1996; Jobbagy and Jackson, 2000), and varies substantially within the same soils or growth media for different cultivars of the same plant, and between different cultivars of the same parent.

Canadell et al. (1996a) reviewed rooting depth from 290 observations of maximum rooting depth for 253 woody and herbaceous species and found maximum rooting depth ranged from $0.3 \mathrm{~m}$ for some tundra species to $68 \mathrm{~m}$ for Boscia albitrunca in the central Kalahari. In this analysis, 194 species had roots at least 2-m deep, 50 species had roots with a depth of $5 \mathrm{~m}$ or more and 22 species with rooting depth to $10 \mathrm{~m}$ or deeper (Canadell et al., 1996a). The average rooting depth from this comparison was $4.6 \pm 0.5 \mathrm{~m}$. When the maximum rooting depth was segregated by biome the results showed $2.0 \pm 0.3 \mathrm{~m}$ for boreal forest, $2.1 \pm 0.2 \mathrm{~m}$ for cropland, $9.5 \pm$ $2.4 \mathrm{~m}$ for desert, $5.2 \pm 0.8 \mathrm{~m}$ for sclerophyllous shrub land and forest, $3.9 \pm 0.4 \mathrm{~m}$ for temperate coniferous forest, $2.9 \pm 0.2$ $\mathrm{m}$ for temperate deciduous forest, $2.6 \pm 0.2 \mathrm{~m}$ for temperate grassland, $3.7 \pm 0.5 \mathrm{~m}$ for tropical deciduous forest, $7.3 \pm 2.8$ $\mathrm{m}$ for tropical evergreen forest, $15.0 \pm 5.4 \mathrm{~m}$ for tropical grassland/savanna, and $0.5 \pm 0.1 \mathrm{~m}$ for tundra. If the aggregation was conducted across species within biomes (except croplands) by three basic functional groups maximum rooting depth was $7.0 \pm 1.2 \mathrm{~m}$ for trees, $5.1 \pm 0.8 \mathrm{~m}$ for shrubs, and $2.6 \pm 0.1$ $\mathrm{m}$ for herbaceous plants. These analyses data show that deep root habits are quite common in woody and herbaceous species across terrestrial biomes, deeper than previously assumed. These results argue for an enhanced understanding of ecosystem function and its application in developing ecosystem models.

Carbon dioxide enrichment resulted in enhanced root proliferation at shallower soil depths in wheat (Chaudhuri et al., 1990; Fitter et al., 1996; Van Vuuren et al., 1997; Van Vuuren et al., 1997), cotton (Rogers et al., 1992), sorghum (Chaudhuri et al., 1986), and grassland (Fitter et al., 1997). Chaudhuri et al. (1990) found winter wheat grown under elevated $\mathrm{CO}_{2}$ achieved maximum rooting penetration significantly faster than plants grown in ambient air. They also found that root growth differences between ambient and elevated $\mathrm{CO}_{2}$ occurred in the upper $10 \mathrm{~cm}$ of soil and concluded that high levels of $\mathrm{CO}_{2}$ compensate for restriction in growth of wheat roots by drought. In contrast to wheat, Chaudhuri et al. (1986) found root numbers and dry weights of sorghum roots were higher at all depths to $150 \mathrm{~cm}$ under increased $\mathrm{CO}_{2}$. Controlled studies on rooting pattern of cotton plants under FACE (Prior, 1992; Prior et al., 1994a, 2003; Rogers et al., 1993) demonstrated that root architecture, defined as the distribution of fine root density per unit volume of soil and expressed as length or dry weight per $\mathrm{m}^{3}$, increased both vertically and horizontally with increased $\mathrm{CO}_{2}$. Fine root density increased under
$\mathrm{CO}_{2}$ enrichment to $90 \mathrm{~cm}$ with the most significant increase in the upper $45 \mathrm{~cm}$. Root length and dry weight densities exhibited greater difference between ambient and elevated $\mathrm{CO}_{2}$ as distance from row center increased, indicating faster and more prolific spread of cotton roots (Rogers et al., 1994).

Experimental evidence from forested ecosystems shows $\mathrm{CO}_{2}$ enrichment may lead to deeper rooting distributions (Rogers et al., 1994). Altered rooting distributions will affect ecosystem processes and the depth to which fine roots are produced influences root chemistry, physiological function, and mycorrhizal infection, leading to altered $\mathrm{N}$ uptake rates and slower root turnover. Changes in rooting patterns influence nutrient dynamics, thus influencing crop performance when nutrient demand is high. Whole plant nutrient uptake is often higher, while tissue nutrient concentration is reduced for $\mathrm{CO}_{2}$-enriched plants (Prior et al., 1998, 2003; Rogers et al., 1994, 1997). Shifts in rooting patterns alter their competitive effectiveness for edaphic resources. Root proliferation into nutrient-rich zones can be an important mechanism in the exploitation of soil resources (Borkert and Barber, 1985; Jackson and Caldwell, 1989).

\section{Root Branching}

The branching patterns of root systems have been described as "developmentally" (Barley, 1970; Rose, 1983) and "topologically" (Fitter, 1985, 1986, 1987). Previous studies show the primary response of crop plants to elevated $\mathrm{CO}_{2}$ on branching and extension of first-order and higher-order laterals root over the extension of the root system deeper into the soil (Rogers et al., 1999; Pritchard and Rogers, 2000). They suggested that, with higher atmospheric $\mathrm{CO}_{2}$ concentrations, crop roots will be larger, more highly branched (especially at shallow depths), but less efficient in nutrient and water uptake (decreased specific root activity). This hypothesis is supported from observations by Berntson and Bazzaz (1995), demonstrating the potential of root systems to acquire resources may increase because of greater total root length densities; however, there may be a decline in the efficiency of resource capture. Root systems of crops grown in $\mathrm{CO}_{2}-$ enriched environments are often more branched, especially at shallower soil depths, compared to roots of crops grown in ambient air (sorghum, Chaudhuri et al., 1986; wheat, Chaudhuri et al., 1990; Fitter et al., 1996; Caratonia siliqua, Cruz et al., 1997; soybean, Del Castillo et al., 1989; cotton, Rogers et al., 1992; Pilumwong et al., 2007; Senecio vulgaris, Berntson and Woodward, 1992). These observations indicate altered belowground plant function suggesting higher level soil ecological processes may change as atmospheric $\mathrm{CO}_{2}$ continue to increase (Pritchard and Rogers, 2000; Rogers et al., 1997, 1999).

In soybean, Del Castillo et al. (1989) reported no effect on rates of elongation; however, there was an increase in the number of more highly branched roots. Cruz et al. (1997) reported that carob (Ceratonia siliqua L.) seedlings grown in elevated $\mathrm{CO}_{2}$ produced more lateral roots and shorter and thicker roots. In a FACE study with cotton, Rogers et al. (1992) showed that the number, length, and mass of lateral roots were enhanced by $\mathrm{CO}_{2}$ enrichment. Although taproot diameter, mass, and volume were enhanced, length was not affected. In contrast, Rogers et al. (1992) reported an increase in soybean root length but no change in the number of lateral roots. Under FACE studies, the lengths and volumes of taproots, lateral roots, and fine roots were higher 
for $\mathrm{CO}_{2}$-enriched cotton plants but the number of lateral roots per unit length of taproot was not significantly increased, the greater taproot lengths with $\mathrm{CO}_{2}$ enrichment increased total number of laterals (Prior, 1992; Prior et al., 1994a, 1994b; Rogers et al., 1993). Another FACE study on spring wheat by Wechsung et al. (1999) reported a 37\% increase in total root dry mass in the FACE vs. control plots during stem elongation. During early vegetative growth, root dry mass from the inter-row space was significantly higher for FACE compared to control treatments suggesting that elevated $\mathrm{CO}_{2}$ promoted the production of first-order lateral roots per main axis. During the reproductive period of growth, more branching of lateral roots was found in the FACE treatment along with significantly higher root dry mass when soil water supply was limiting. These responses in root growth and morphology to elevated $\mathrm{CO}_{2}$ and reduced soil water supports the hypothesis that plants grown in a high $\mathrm{CO}_{2}$ environment may compensate for soil water stress because of the increased root density ability to extract more water per unit soil volume.

Differential effects of $\mathrm{CO}_{2}$ concentration on root branching may lead to altered root architecture and ability of roots to extract water and nutrients. For example, Berntson and Woodward (1992) observed for Senecio vulgaris grown under elevated $\mathrm{CO}_{2}$ more horizontal branching angles of roots leading to greater horizontal root spread. Rogers et al. (1992) observed longer second-order laterals in soybean, which could lead to deeper root penetration and greater exploration of soil for nutrients and water but could ultimately lead to competition among roots in resource-limited environments. Conversely, Del Castillo et al. (1989) found more roots attributed to increased branching rather than longer roots in soybean grown under enriched $\mathrm{CO}_{2}$. The positive effect of increased root numbers leads to more efficient exploration of the same volume of soil compared to deeper root penetration (Pritchard et al., 1999). Increasing $\mathrm{CO}_{2}$ caused increased root branching across species suggesting that greater root exploration of the profile would occur as a result of the positive effect of $\mathrm{CO}_{2}$ on root growth (Table 1).

\section{Root Thickness, Quality, and Diameter}

The additional root biomass production from elevated $\mathrm{CO}_{2}$ induced increased thickness or diameter or quality (root length density) of plant roots and increased total root length and volume along with root diameter in the root hair zone and length of unbranched first-order laterals (Rogers et al., 1992). Roots become more numerous, longer, thicker, and faster growing in crops grown under high $\mathrm{CO}_{2}$ (Chaudhuri et al., 1990; Prior et al., 1994a, 1994b, 1995) and the diameters of dead roots did not differ from the diameter of roots that remained alive during the crop growth period of sorghum (Pritchard et al., 2006). Changes in root dry weight density caused by $\mathrm{CO}_{2}$ enrichment suggests possible changes in root quality. The results of a FACE experiment on cotton by Prior et al. (1994a, 1994b) showed large shifts in root dry weight density. These results suggest possible changes in root quality from changes in root dry weight density through changes in tissue density of roots (fine and taproots) resulting in shifts in carbohydrate storage, cell number, cell size, and percentage of intercellular space or other structural modifications. Soybean plants grown under $\mathrm{CO}_{2}$ enrichment exhibited a $27 \%$ increase in root diameter, stele diameter (23\%), and cortex width (28\%) in the root hair zone (Rogers et al., 1992). Studies on structural aspects of plant roots (i.e., diameter, volume, branching, relative growth rate, etc.) have usually shown positive effects of high $\mathrm{CO}_{2}$. Tubers (number, dry weight, diameter, etc.) and nodulation (number, dry weight, activity, etc.) benefit from elevated $\mathrm{CO}_{2}$ in most crops (Rogers et al., 1994).

Zhao et al. (2000) germinated pea (Pisum sativum L.) seeds and exposed the young plants to various atmospheric $\mathrm{CO}_{2}$ concentrations in controlled environment chambers to determine if elevated $\mathrm{CO}_{2}$ impacted root border cells, which are major contributors of root exudates in most agronomic plants. They found elevated $\mathrm{CO}_{2}$ increased the production of root border cells in pea seedlings. Changing the ambient air to air enriched with 3000 and $6000 \mu \mathrm{mol} \mathrm{mol}^{-1} \mathrm{CO}_{2}$, border-cell numbers increased by more than 50 and $100 \%$, respectively. It is likely that continued increases of $\mathrm{CO}_{2}$ will likely produce greater numbers of root border cells in crop plants and lead to increased amounts of root exudates into the rhizosphere, suggesting that associated soil microbial and fungal activities would be stimulated from increases in plant-derived $\mathrm{C}$ inputs. These changes should make the soil environment more favorable for plant growth and development in a high $\mathrm{CO}_{2}$ environment. Few studies have addressed $\mathrm{CO}_{2}$-induced changes in root quality/thickness/diameter and structure and further research is needed, especially under field environments (Table 1).

\section{Root Mortality/Root Turnover}

Root turnover is important to the global $\mathrm{C}$ budget as well as to nutrient cycling in ecosystems and to the success of individual plants in obtaining water and nutrients. Replacement of older roots with newly formed roots is referred to as root turnover. Root turnover is estimated from the difference between cumulative births and deaths, which represents either a net accumulation or disappearance of roots. If roots are not accumulating even though production is enhanced, then turnover must be equally enhanced (i.e., birth rate equals death rate). The difference in accumulation rate between elevated and ambient $\mathrm{CO}_{2}$ levels can be used to determine whether turnover is affected by $\mathrm{CO}_{2}$ and a positive difference means that roots are accumulating faster under elevated $\mathrm{CO}_{2}$. There are several papers discussing approaches for estimating annual root turnover (Milchunas et al., 1985; Caldwell and Eissenstat, 1987; Hendrick and Pregitzer, 1992; Milchunas and Lauenroth, 1992; Hendricks et al., 1993; Fahey and Hughes, 1994), which reveal no consensus on the best approach for estimating root turnover. Del Castillo et al. (1989) observed a significant linear increase in the number of actively growing roots of soybean with increased $\mathrm{CO}_{2}$ compared to elongation rate. Eissenstat et al. (2000) applied an efficiency model to hypothesize that rising $\mathrm{CO}_{2}$ would increase average root lifespan. In contrast, other investigators have suggested root lifespan is unlikely to change with increasing $\mathrm{CO}_{2}$ (Pritchard and Rogers, 2000; van Noordwijk et al., 1998).

Increased photosynthesis under elevated $\mathrm{CO}_{2}$ stimulates belowground $\mathrm{C}$ input, fine-root growth (Curtis, 1996; Curtis and Wang, 1998; Pendall et al., 2005) and root turnover rates and biomass (Berntson and Bazzaz, 1997b; Fitter et al., 1999; Allen et al., 2000; Pregitzer et al., 2000; Wan et al., 2004). Increased fine-root production and mortality are associated with higher temperatures (Gill and Jackson, 2000) and turnover rates (Hendrick and Pregitzer, 1993b, 1997; Forbes et al., 
1997; Fitter et al., 1999; King et al., 1999; Wan et al., 2004). Turnover rates increase with increased $\mathrm{C}$ allocation to root systems when plants are grown under elevated $\mathrm{CO}_{2}$, at least in grasslands and forest (Fitter et al., 1996). Root life span is highly variable, from a few weeks in some plants to a few years in others (Eissenstat and Yanai, 1997). Root longevity varies widely within an individual species.

Fine roots are essential for plant water and nutrient uptake, soil C input, and soil microbial activity (Eissenstat, 1992; Norby, 1994). Turnover of fine roots (<2.0-mm diam.) play a critical role in regulating ecosystem $\mathrm{C}$ balance and accurate estimates of belowground net primary productivity (NPP) are required for estimating net ecosystem productivity (NEP) (Pendall et al., 2005). As much as 33\% of global annual NPP has been estimated for the production of fine roots (Jackson et al., 1997). Caldwell (1977) suggested for perennial systems, at least $25 \%$ of root systems die and replaced annually, accounting for as much as 50 to $80 \%$ of net production. Death of older roots and the growth of new ones are a significant energetic cost to the plant (Canadell et al., 1996b). Understanding the trade-offs between the cost of maintaining old roots compared with that of growing new ones is an important step in understanding how increased $\mathrm{C}$ assimilation, associated with rising global $\mathrm{CO}_{2}$ affects root turnover. van Noordwijk et al. (1998) developed a quantitative model for this system by estimating for a root with a growth respiration of $2 \mathrm{~g} \mathrm{CH}_{2} \mathrm{O} \mathrm{g} \mathrm{g}^{-1}$ root dry weight and a maintenance respiration of $0.03 \mathrm{~g} \mathrm{Cg}^{-1}$ root dry weight, approximately $60 \mathrm{~d}$ of root maintenance in unfavorable conditions would cost as much as one cycle of root death followed by regrowth. van der Werf et al. (1988) showed, for a different species, that the adenosine-5'-triphosphate (ATP) costs of producing $1 \mathrm{~g}$ fresh wt. of root is approximately equal to the cost of maintaining $1 \mathrm{~g}$ of root for $10 \mathrm{~d}$. The implications of this energy balance for roots suggest it may be more energetically expensive to maintain one root when the costs of maintenance during periods of stress exceed the energy requirements of growing new roots on the return of favorable soil conditions.

The availability of underground resources (water and nutrients) influences the $\mathrm{C}$ allocation to roots and turnover rates. If we follow the argument of Stulen and den Hertog (1993) that plants grown under non-limiting conditions do not alter their allocation of $\mathrm{C}$ between roots and shoots under elevated atmospheric $\mathrm{CO}_{2}$ then the hypothesis of van Noordwijk et al. (1998) that increasing atmospheric $\mathrm{CO}_{2}$ is not likely to have a significant direct effect caused by a greater $\mathrm{C}$ supply on root turnover. However, indirect effects, mediated by shifts in plant water availability and nutrient relations, are likely to affect root turnover. Experimental evidence shows that root turnover increases more often than not when soil conditions are limiting root uptake (Pregitzer et al., 1995; Canadell et al., 1996b). Canadell et al. (1996b) found from four experiments with grass systems there was increased root turnover in three with no change in one experiment. In four experiments on trees, increased turnover was observed in three, while one showed a decrease (Canadell et al., 1996b). Finally, no difference in root turnover was observed in wheat grown in elevated $\mathrm{CO}_{2}$ (Fitter et al., 1996). It is likely that root turnover will be different between annual and perennial plants.

Temporal pattern of root growth is consistent with $\mathrm{C}$ allocation to roots being highest during early vegetative growth and decreasing as plants mature and transition to reproductive growth (Swinnen et al., 1994). Pritchard et al. (2006) concluded daily production of new roots in sorghum occurred primarily in the early part of the growing season and daily mortality of roots increased steadily over the growing season in a linear fashion under elevated $\mathrm{CO}_{2}$. The death of roots and growth of new roots corresponds to the availability of soil water and nutrients (Huck et al., 1987; Smucker, 1993). Huck et al. (1987) found that birth and death rates of roots were mediated in time by rainfall events and in space by moist soil microsites. They observed that the number of active soybean roots decreased after each rain, increased rapidly during dry periods, and declined after subsequent rainfall events. They observed spatial peaks in root growth during dry conditions occurred in the soil profile where soil moisture was favorable (Huck et al., 1987). Resource availability (nutrients, moisture, and temperature) in the top layer of soil plays a key role on the rate of fine root mortality. Pritchard et al. (1999) found a negative linear relationship between soil depth and the proportion of roots that died in sorghum with a similar conclusion made on alfalfa roots (Goins and Russelle, 1996; Watson et al., 2000), groundnut (Krauss and Deacon, 1994), and sugar beet (van Noordwijk et al., 1994). Changes in nutrient availability, temperature, and moisture throughout a day with depth a possible explanation for these observations because of the greater change in the upper soil layers compared to deeper layers (Watson et al., 2000). In tree species, rates of fine root mortality was roughly twice as in trees grown at elevated $\mathrm{CO}_{2}$ compared to ambient $\mathrm{CO}_{2}$ in both high and low soil N (Pregitzer et al., 1995).

The projected increases in air temperatures, changing precipitation patterns, and potential decreases in soil nutrients availability could be expected to have impacts on root mortality (Rastetter et al., 1997). Root mortality might be accelerated by decreases in soil moisture (Klepper et al., 1973; Hayes and Seastedt, 1987; Huck et al., 1987) or by increases in soil temperature (Fitter et al., 1999). However, root mortality might be reduced by decreased availability of nutrients (Eissenstat and Yanai, 1997). Fitter et al. (1997) observed in peat and limestone grassland soils, cumulative root birth and death totals were greater under elevated $\mathrm{CO}_{2}$. In the peat soil, cumulative births were $20 \%$ greater ( 36 as compared to 30 per tube) and deaths $21 \%$ greater (34 and 28 per tube) after two seasons under elevated $\mathrm{CO}_{2}$. In the limestone soil, cumulative births were increased by $30 \%(35$ vs. 27) and deaths by $29 \%$ (31 vs. 24). Turnover was faster under elevated $\mathrm{CO}_{2}$ in the peat soil, but there was only a small effect on turnover in the limestone soil (Fitter et al., 1997).

Finally, it's suggested that more long-term studies are needed, to detect both existing patterns of root mortality and lifespan with resource availability and plant strategy, and to progress beyond short-term studies, which may be misleading. Factors that should be included in studies of root lifespan, in addition to resource availability, include root age, plant $\mathrm{C}$ status, and pathogen pressure. The effects of increasing $\mathrm{CO}_{2}$ on root mortality are less clear and the linkage to changes in temperature and soil water has been difficult to quantify.

\section{Conclusions and Recommendations}

Crops grown under elevated atmospheric $\mathrm{CO}_{2}$ exhibit changes in above- and belowground growth responses which 
could potentially lead to alteration in plant communities. Increased allocation of $\mathrm{C}$ to roots may stimulate lateral rooting with extensive root branching. Rooting depth of roots will be influenced by availability of water, nutrients, and other resources in the soil profile. The greater proliferation of roots under elevated atmospheric $\mathrm{CO}_{2}$ will lead to higher extraction of soil resources with less efficient rooting systems. Carbon dioxide often suppresses plant water use, increasing water use efficiency with relatively less water flow within the plant and consequently in the soil matrix. The enhanced proliferation of roots grown under elevated atmospheric $\mathrm{CO}_{2}$ concentration may be a strategy which permits adequate nutrient acquisition in the absence of normal water absorption rates. Deeper roots could penetrate into deeper soils to create more resilience to droughts in natural plant communities and agronomic crops. This deeper rooting would be an advantage if climates became drier and altered belowground plant competition.

Variability in response of plant root to $\mathrm{CO}_{2}$ have been observed in response to the interacting effects of $\mathrm{CO}_{2}$ with other climatic factors and soil resources coupled with species and even genotypic variability along with levels of the treatment variables. In addition, environmental changes concomitant with the rise of atmospheric $\mathrm{CO}_{2}$ levels might substantially modify plant and ecosystem level responses. For example, some studies suggest that plants subjected to water stress will respond more favorably to elevated $\mathrm{CO}_{2}$ while other studies report the opposite response.

Enhanced root growth and biomass production from exposure to increased $\mathrm{CO}_{2}$ concentrations could deliver more $\mathrm{C}$ to the soil profile potentially altering rhizosphere microbiology (populations and dynamics); and inducing possible physicochemical changes in soil by increasing root activity, including rhizodeposition due to root turnover. It is evident from several studies that increasing levels of $\mathrm{CO}_{2}$, will have virtually no adverse effects on plant root growth except where decreases in efficiency of root systems (specific root activity) and inability of roots to acquire nutrients due to reduced water use/uptake to keep pace with the increased $\mathrm{C}$ assimilation would have negative consequences on crop productivity and nutrient content in aboveground organs.

Under favorable conditions of water and nutrients for growth, dry matter partitioning to the root is not altered by $\mathrm{CO}_{2}$ enrichment. The increase in $\mathrm{R} / \mathrm{S}$, frequently observed under limiting conditions of water and/or nutrients, enables the plant to explore a greater soil volume and extract more water and nutrients.

However, there are many debates on whether $R / S$ is valuable as a standard root variable due to our inability to accurately estimate belowground biomass, particularly fine roots, root turnover biomass at later stages of the crop and at deeper soil depth apart from microbial decomposition of roots. As observed from many studies, plants allocate more $\mathrm{C}$ toward the root growth in the early vegetative stage of development and then decrease. Static assessments of belowground productivity at different stages of crop grow th may greatly underestimate the root biomass leading to an exaggeration of $R / S$ values.

Root lifespan has important consequences for plant growth and productivity, plant competition, and $\mathrm{C}$ and nutrient cycling. Very limited information is available to quantify the effects of elevated $\mathrm{CO}_{2}$ on the trade-offs associated with maintaining old roots in comparison with growing new roots. Long-term studies are needed to detect existing patterns of root lifespan with resource availability and plant strategy and to progress beyond short-term responses to treatments. Factors that should be included in studies of root lifespan in addition to resource availability include root age, plant $\mathrm{C}$ status, and pathogen pressure. Because root lifespan differs from leaf lifespan in many species, better knowledge of root lifespan may result in revision of current theories regarding plant adaptation and growth strategies.

Agricultural management practices may have a greater impact on root growth than rising atmospheric $\mathrm{CO}_{2}$ since management practices influence soil physical, chemical, and biological properties of soil, and consequently root growth dynamics. Less understood are the interactive effects of elevated $\mathrm{CO}_{2}$ and management practices (tillage, soil moisture, and nutrients) including drought on root dynamics, fine-root production and water-nutrient use efficiency, and the contribution of these processes to plant growth in water and nutrient-limited environments. Increases in water use efficiency and reductions in water use can contribute to enhanced soil water content under elevated $\mathrm{CO}_{2}$.

Roots are difficult to study because they are hidden within the soil profile and extraction methods destroy the sample. The advent of nondestructive techniques, that is, minirhizotrons or rhizotrons, provide a method of visual and qualitative assessments but do not permit quantitative evaluations of the changes in root biomass or detailed examinations of the branching or root turnover rates. The current state of knowledge regarding root systems is rather simplistic because of the methodological limitations; however, these studies have begun to show that there will be effects of increasing $\mathrm{CO}_{2}$ on the roots along with the shoots and these responses will have impacts on the utilization of the soil resources, water, nutrients, gases, and temperature. We can continue to strive for more detailed understanding of root responses to changing $\mathrm{CO}_{2}$; however, these should not be done without considering the interactions with the soil environment. An aspect which is evident from the combined literature is that root function under increased $\mathrm{CO}_{2}$ does increase when there is no limitation from water, nutrients, or temperature which does suggest that under climate change adoption of management practices which reduces the occurrence of these stresses will have a positive benefit on plant growth and productivity. Understanding these processes will provide the foundation for design of future adaptation and mitigation strategies linking improved soil management practices with crop and root response to increasing $\mathrm{CO}_{2}$ and will provide a structure for improving the stability of agriculture under climate change.

\section{REFERENCES}

Allen, A.S., J.A. Andrews, A.C. Finzi, R. Matamala, D.D. Richter, and W.H. Schlesinger. 2000. Effects of free-air $\mathrm{CO}_{2}$ enrichment (FACE) on belowground processes in Pinus taeda forest. Ecol. Appl. 10:437-448.

Allen, L.H., J.C.V. Vu, R.R. Valle, K.J. Boote, and P.H. Jones. 1988. Nonstructural carbohydrates and nitrogen of soybean grown under carbon dioxide enrichment. Crop Sci. 28:84-94. doi:10.2135/cropsci1988.0011183X002 $800010020 \mathrm{x}$

Baker, J.T., L.H. Allen, and K.J. Boote. 1990. Growth and yield responses of rice to carbon dioxide concentrations. J. Agric. Sci. 115:313-320. doi:10.1017/ S0021859600075729

Baker, J.M., T.E. Ochsner, R.T. Venterea, and T.J. Griffis. 2007. Tillage and soil carbon sequestration-What do we really know? Agric. Ecosyst. Environ. 118:1-5. doi:10.1016/j.agee.2006.05.014

Barber, D.A., and J.K. Martin. 1976. The release of organic substances by cereal roots in soil. New Phytol. 76:69-80. doi:10.1111/j.1469-8137.1976. tb01439.x 
Barley, K.P. 1970. The configuration of the root system in relation to nutrient uptake. Adv. Agron. 22:159-201. doi:10.1016/S0065-2113(08)60268-0

Batjes, N.H. 1996. Total carbon and nitrogen in the soils of the world. Eur. J. Soil Sci. 47:151-163. doi:10.1111/j.1365-2389.1996.tb01386.x

Baxter, B., T.W. Ashenden, T.H. Sparks, and J.F. Farrar. 1994. Effects of elevated carbon dioxide on three montane grass species. I. Growth and dry matter partitioning. J. Exp. Bot. 45(3):305-315. doi:10.1093/jxb/45.3.305

Bazzaz, F.A. 1990. Response of natural ecosystems to the rising global $\mathrm{CO}_{2}$ levels. Annu. Rev. Ecol. Syst. 21:167-196. doi:10.1146/annurev. es.21.110190.001123

Bernacchi, C.J., J.S. Coleman, F.A. Bazzaz, and K.D.M. McConnaughay. 2000. Biomass allocation in old-field annual species grown in elevated $\mathrm{CO}_{2}$ environments: No evidence for optimal partitioning. Glob. Change Biol. 6:855863. doi:10.1046/j.1365-2486.2000.00370.x

Berntson, G.M., and F.A. Bazzaz. 1995. Belowground positive and negative feedbacks on $\mathrm{CO}_{2}$ growth enhancement. Plant Soil 187:119-131. doi:10.1007/ BF00017085

Berntson, G.M., and F.A. Bazzaz. 1997a. Nitrogen cycling in microcosms of yellow birch exposed to elevated $\mathrm{CO}_{2}$ : Simultaneous positive and negative below-ground feedbacks. Glob. Change Biol. 3:247-258. doi:10.1046/j.1365-2486.1997.00070.x

Berntson, G.M., and F.A. Bazzaz. 1997b. Elevated $\mathrm{CO}_{2}$ and the magnitude and seasonal dynamics of root production and loss in Betula papyrifera. Plant Soil 190:211-216. doi:10.1023/A:1004222131516

Berntson, G.M., and F.I. Woodward. 1992. The root system architecture and development of Senecio vulgaris in elevated $\mathrm{CO}_{2}$ and drought. Funct. Ecol. 6:324-333. doi:10.2307/2389524

Bhattacharya, N.C., D.R. Hileman, P.P. Ghosh, R.L. Musser, S. Bhattacharya, and P.K. Biswas. 1990. Interaction of enriched $\mathrm{CO}_{2}$ and water stress on the physiology and production in sweet potato grown in open-top chambers. Plant Cell Environ. 13:933-940. doi:10.1111/j.1365-3040.1990.tb01983.x

Biswas, P.K., and D.R. Hileman. 1985. Response of vegetation to carbon dioxide: Field studies of sweet potatoes and cowpeas in response to elevated carbon dioxide. Rep. 022. U.S. Dep. of Energy. Carbon Dioxide Res. Div., Office of the Energy Res., Washington, DC.

Borkert, C.M., and S.A. Barber. 1985. Soybean shoot and root growth and phosphorus concentration as affected by phosphorus placement. Soil Sci. Soc. Am. J. 49:152-155. doi:10.2136/sssaj1985.03615995004900010031x

Bradley, R.I., R. Milne, J. Bell, A. Lilly, C. Jordan, and A. Higgins. 2005. A soil carbon and land use database for the United Kingdom. Soil Use Manage. 21:363-369. doi:10.1079/SUM2005351

Burch, G.J., and G.G. Johns. 1978. Root absorption of water and physiological responses to water deficits by Festuca arundinacea Shrub and Trifolim repens (L.). Aust. J. Plant Physiol. 5:859-871. doi:10.1071/PP9780859

Caldwell, M.M. 1977. Root structure: The considerable cost of belowground function. In: O.T. Solbrig, editor, Topics in plant population biology. Columbia Univ. Press, New York. p. 408-427.

Caldwell, M.M., and D.M. Eissenstat. 1987. Coping with variability: Examples of tracer use in root function studies. In: J.D. Tenhunen et al., editors, Plant response to stress. NATO AS1 Series 15G. Springer-Verlag, Berlin. p. 95-106.

Canadell, J.R., B. Jackson, J.B. Ehleringer, H.A. Mooney, O.E. Sala, and E.D. Schulze. 1996a. Maximum rooting depth of vegetation types at the global scale. Oecologia 108:583-595. doi:10.1007/BF00329030

Canadell, J.G., L.F. Pitelka, and J.S.I. Ingram. 1996b. The effects of elevated $\mathrm{CO}_{2}$ on plant-soil carbon below ground: Summary and conclusions. Plant Soil 187:391-400. doi:10.1007/BF00017102

Ceulemans, R., and M. Mousseau. 1994. Effects of elevated atmospheric $\mathrm{CO}_{2}$ on woody plants. New Phytol. 127:425-446. doi:10.1111/j.1469-8137.1994. tb03961.x

Chaudhuri, U.N., R.B. Burnett, M.B. Kirkham, and E.T. Kanemasu. 1986. Effect of carbon dioxide on sorghum yield, root growth, and water use. Agric. For. Meteorol. 37:109-122. doi:10.1016/0168-1923(86)90002-X

Chaudhuri, U.N., M.B. Kirkham, and E.T. Kanemasu. 1990. Root growth of winter wheat under elevated carbon dioxide and drought. Crop Sci. 30:853-857. doi:10.2135/cropsci1990.0011183X003000040017x

Cornish, K., and J.A.D. Zeevaart. 1985. Abscisic acid accumulation in roots of Xanthium strumarium (L.) and Lycopersicon esculentum (Mill.). In relation to water stress. Plant Physiol. 79:653-658. doi:10.1104/pp.79.3.653

Cox, W.J., R.W. Zobel, H.M. Van Es, and D.J. Otis. 1990. Tillage effects on some soil physical and corn physiological characteristics. Agron. J. 82:806-812. doi:10.2134/agronj1990.00021962008200040030x
Cruz, C., S.H. Lips, and M.A. Martins-Loucao. 1997. Changes in the morphology of roots and leaves of carob seedlings induced by nitrogen source and atmospheric carbon dioxide. Ann. Bot. (London) 80:817-823. doi:10.1006/ anbo.1997.0524

Cure, J.D. 1985. Carbon dioxide doubling responses: A crop survey. In: B.R. Strain and J.D. Cure, editors, Direct effects of increasing carbon dioxide on vegetation. DOE/ER-0238. U.S. Dep. of Energy, Washington, DC. p. 99-116.

Curtis, P.S. 1996. A meta-analysis of leaf gas exchange and nitrogen in trees grown under elevated carbon dioxide. Plant Cell Environ. 19:127-137. doi:10.1111/j.1365-3040.1996.tb00234.x

Curtis, P.S., L.M. Balduman, B.G. Drake, and D.F. Whigham. 1990. Elevated atmospheric $\mathrm{CO}_{2}$ effects on belowground processes in $\mathrm{C}_{3}$ and $\mathrm{C}_{4}$ estuarine marsh communities. Ecology 71:2001-2006. doi:10.2307/1937608

Curtis, P.S., and X. Wang. 1998. A meta-analysis of elevated $\mathrm{CO}_{2}$ effects on woody plant mass, form and physiology. Oecologia 113:299-313. doi:10.1007/ s004420050381

Dahlman, R.C., B.R. Strain, and H.H. Rogers. 1985. Research on the response of vegetation to elevated atmospheric carbon dioxide. J. Environ. Qual. 14:1-8. doi:10.2134/jeq1985.00472425001400010001x

Davidson, R.L. 1969. Effect of root: Leaf temperature differentials on root:shoot ratios in some pasture grasses and clover. Ann. Bot. (London) 33:561-569.

Del Castillo, D., B. Acock, V.R. Reddy, and M.C. Acock. 1989. Elongation and branching of roots on soybean plants in a carbon dioxide-enriched aerial environment. Agron. J. 81:692-695. doi:10.2134/agronj1989.000219620 08100040026x

Derner, J.D., H.B. Johnson, B.A.K. Iimball, P.J. Pinter, Jr., H.W. Polley, C.R. Tischler et al. 2003. Above and below ground responses of $C_{3}$ and $C_{4}$ species mixtures in elevated $\mathrm{CO}_{2}$ and soil water availability. Glob. Change Biol. 9:452-460. doi:10.1046/j.1365-2486.2003.00579.x

Drake, B.G., and M.A. Gonzàlez-Meier. 1997. More efficient plants: A consequence of rising atmospheric $\mathrm{CO}_{2}$ ? Annu. Rev. Plant Physiol. 48:609-639. doi:10.1146/annurev.arplant.48.1.609

Dwyer, L.M., B.L. Ma, H.N. Hayhoe, and J.L.B. Culley. 1995. Tillage effects on soil temperature shoot dry matter accumulation and corn grain yield. J. Sustain. Agric. 5:85-99. doi:10.1300/J064v05n01_07

Dwyer, L.M., B.L. Ma, D.W. Stewart, H.N. Hayhoe, D. Balchin, J.L.B. Culley, and M. McGovem. 1996. Root mass distribution under conventional and conservation tillage. Can. J. Soil Sci. 76:23-28. doi:10.4141/cjss96-004

Eamus, D., and P.G. Jarvis. 1989. Direct effects of $\mathrm{CO}_{2}$ increases on trees and forests (natural and commercial) in the UK. Adv. Ecol. Res. 19:1-55. doi:10.1016/ S0065-2504(08)60156-7

Eissenstat, D.M. 1992. Costs and benefits of constructing roots of small diameter. J. Plant Nutr. 15:763-782. doi:10.1080/01904169209364361

Eissenstat, D.M., and R.D. Yanai. 1997. The ecology of root life span. Adv. Ecol. Res. 27:1-62. doi:10.1016/S0065-2504(08)60005-7

Eissenstat, D.M., C.E. Wells, R.D. Yanai, and J.L. Whitbeck. 2000. Building roots in a changing environment: Implications for root longevity. New Phytol. 147:33-42. doi:10.1046/j.1469-8137.2000.00686.x

Fahey, T.J., and J.W. Hughes. 1994. Fine root dynamics in a northern hardwood forest ecosystem Hubbard Brook Experimental Forest, NH. J. Ecol. 82:533548. doi: $10.2307 / 2261262$

Ferris, R., and G. Taylor. 1993. Contrasting effects of elevated on the root and shoot growth of four native herbs commonly found in chalk grassland. New Phytol. 125:855-866. doi:10.1111/j.1469-8137.1993.tb03934.x

Fitter, A.H. 1985. Functional significance of root morphology and root system architecture. In: A.H. Fitter et al., editors, Ecological interactions in soil. Blackwell Scientific Publ., Oxford. p. 87-106.

Fitter, A.H. 1986. The topology and geometry of plant root systems: Influence of watering rate on root system topology in Trifolium pratense. Ann. Bot. (London) 58:91-101.

Fitter, A.H. 1987. An architectural approach to the comparative ecology of plant root systems. New Phytol. 106:61-77. doi:10.1111/j.1469-8137.1987. tb04683.x

Fitter, A.H., J.D. Graves, J. Wolfenden, G.K. Self, T.K. Brown, D. Bogie, and T.A. Mansfield. 1997. Root production and turnover and carbon budgets of two contrasting grasslands under ambient and elevated atmospheric carbon dioxide concentrations. New Phytol. 137:247-255. doi:10.1046/j.1469-8137.1997.00804.x

Fitter, A.H., G.K. Self, T.K. Brown, D. Bogie, J.D. Graves, D. Benham, and P. Ineson. 1999. Root production and turnover in an upland grassland subjected to artificial soil warming respond to radiation flux and nutrients, not temperature. Oecologia 120:575-581. doi:10.1007/s004420050892 
Fitter, A.H., G.K. Self, J. Wolfenden, M.M.I. Van Vuuren, T.K. Brown, L. Williamson et al. 1996. Root production and mortality under elevated atmospheric carbon dioxide. Plant Soil 187:299-306. doi:10.1007/BF00017095

Forbes, P.J., K.E. Black, and J.E. Hooker. 1997. Temperature-induced alteration to root longevity in Lolium perenne. Plant Soil 190:87-90. doi:10.1023/A:1004298804353

French, C.J., and J. Alsbury. 1989. Supplementary lighting and $\mathrm{CO}_{2}$ mist influence rooting of Camellia japonica. HortScience 24:452-454.

Gill, R.A., and R.B. Jackson. 2000. Global patterns of root turnover for terrestrial ecosystems. New Phytol. 147:13-31.doi:10.1046/j.1469-8137.2000.00681.x

Goins, G.D., and M.P. Russelle. 1996. Fine root demography in alfalfa (Medicago sativa (L.)). Plant Soil 185:281-291. doi:10.1007/BF02257534

Guo,L.B.,andR.M.Gifford.2002.Soilcarbonstocksandlandusechange:Ametaanalysis. Glob. Change Biol. 8:345-360. doi:10.1046/j.1354-1013.2002.00486.x

Guswa, A.J. 2010. Effect of plant-uptake strategy on the water optimal root depth. Water Resour. Res. 46:W09601 10.1029/2010WR009122. doi:10.1029/2010WR009122

Hanley, M., S. Troðmov, and G. Taylor. 2004. Species level effects more important than functional group level responses to elevated $\mathrm{CO}_{2}$ : Evidence from simulated turves. Funct. Ecol. 18:304-313. doi:10.1111/j.0269-8463.2004.00845.x

Hatfield, J.L., K.J. Boote, B.A. Kimball, L.H. Ziska, R.C. Izaurralde, D. Ort et al. 2011. Climate impacts on agriculture: Implications for crop production. Agron. J. 103:351-370.

Havelka, U.D., V.A. Wittenbach, and M.G. Boyle. 1984. $\mathrm{CO}_{2}$ enrichment effects on wheat yield and physiology. Crop Sci. 24:1163-1168. doi:10.2135/cropsc i1984.0011183X002400060037x

Hayes, D.C., and T.R. Seastedt. 1987. Root dynamics of tall grass prairie in wet and dry years. Can. J. Bot. 65:787-791. doi:10.1139/b87-105

Heinemann, A.B., H.N. Maia Ad, D. Dourado-Neto, K.T. Ingram, and G. Hoogenboom. 2006. Soybean [Glycine $\max$ (L.) Merr.] growth and development response to $\mathrm{CO}_{2}$ enrichment under different temperature regimes. Eur.J. Agron. 24:52-61. doi:10.1016/j.eja.2005.04.005

Helal, H.M., and D. Sauerbeck. 1986. Effect of plant roots on carbon metabolism of soil microbial biomass. Z. Pflanzenernaehr. Bodenkd. 149:181-188. doi:10.1002/jpln.19861490205

Hendrick, R.L., and K.S. Pregitzer. 1992. The demography of fine roots in a northern hardwood forest. Ecology 73:1094-1104. doi:10.2307/1940183

Hendrick, R.L., and K.S. Pregitzer. 1993a. The dynamics of fine root length, biomass, and nitrogen content in two northern hardwood ecosystems. Can. J. For. Res. 23:2507-2520. doi:10.1139/x93-312

Hendrick, R.L., and K.S. Pregitzer. 1993b. Patterns of fine root mortality in two sugar maple forests. Nature (London) 361:59-61. doi:10.1038/361059a0

Hendrick, R.L., and K.S. Pregitzer. 1997. The relationship between fine root demography and the soil environment in northern hardwood forests. Ecoscience 4:99-105.

Hendricks, J.J., K.J. Nadelhoffer, and J.D. Aber. 1993. Assessing the role of fine roots in carbon and nutrient cycling. Trends Ecol. Evol. 8:174-178. doi:10.1016/0169-5347(93)90143-D

Hocking, P.J., and C.P. Meyer. 1991. Effects of $\mathrm{CO}_{2}$ enrichment and nitrogen stress on growth, and partitioning of dry matter and nitrogen in wheat and maize. Aust. J. Plant Physiol. 18:339-356. doi:10.1071/PP9910339

Hodge, A., and P. Millard. 1998. Effect of elevated $\mathrm{CO}_{2}$ on carbon partitioning and exudates release from Plantago lanceolata seedlings. Physiol. Plant. 103:280-286. doi:10.1034/j.1399-3054.1998.1030216.x

Huck, M.G., G. Hoogenboom, and C.M. Peterson. 1987. Soybean root senescence under drought stress. In: H.M. Taylor, editor, Minirhizotron observation tubes: Methods and applications for measuring rhizosphere dynamics. ASA Spec. Publ. 50. ASA, Madison, WI.

Idso, S.B., and B.A. Kimball. 1991. Effects of two and a half years of atmospheric $\mathrm{CO}_{2}$ enrichment on the root density distribution of threeyear-old sour orange trees. Agric. For. Meteorol. 55:345-349. doi:10.1016/0168-1923(91)90070-7

Idso, S.B., and B.A. Kimball. 1992. Seasonal root growth of sour orange trees maintained in atmospheres of ambient and elevated $\mathrm{CO}_{2}$ concentrations. Plant Cell Environ. 15:337-341. doi:10.1111/j.1365-3040.1992.tb00982.x

Idso, S.B., B.A. Kimball, and J.R. Mauney. 1988. Effects of atmospheric $\mathrm{CO}_{2}$ enrichment on root:shoot ratios of carrot, radish, cotton and soybean. Agric. Ecosyst. Environ. 21:293-299. doi:10.1016/0167-8809(88)90095-3

Imai, K., D.F. Coleman, and T. Yanagisawa. 1985. Increase in atmospheric partial pressure of carbon dioxide and growth and yield office (Oryza sativa (L.)). Jpn. J. Crop. Sci. 54:413-418. doi:10.1626/jcs.54.413
Imai, K., and Y. Murata. 1976. Effect of carbon dioxide concentration on growth and dry matter production in crop plants. Japanese J. of Crop Sci. 45:598606. doi: $10.1626 /$ jcs. 45.598

IPCC. 2001. Climate change 2001: The scientific basis. Cambridge Univ. Press, Cambridge, UK.

IPCC. 2007. Climate change 2007: The physical science basis. Contribution of Working Group I to the Fourth Assessment Report of the Intergovernmental Panel on Climate Change. Cambridge Univ. Press, Cambridge, UK.

Jackson, R.B., and M.M. Caldwell. 1989. The timing and degree of root proliferation in fertile-soil microsites for three cold-desert perennials. Oecologia 81:149-153.

Jackson, R.B., J. Canadell, J.R. Ehleringer, H.A. Mooney, O.E. Sala, and E.D. Schulze. 1996. A global analysis of root distributions for terrestrial biomes. Oecologia 108:389-411. doi:10.1007/BF00333714

Jackson, R.B., H.A. Mooney, and E.D. Schulze. 1997. A global budget for fineroot biomass, surface area, and nutrient contents. Proc. Natl. Acad. Sci. USA 94:7362-7366. doi:10.1073/pnas.94.14.7362

Jobbagy, E.G., and R.B. Jackson. 2000. The vertical distribution of soil organic carbon and its relation to climate and vegetation. Ecol. Appl. 10:423-436. doi:10.1890/1051-0761(2000)010[0423:TVDOSO]2.0.CO;2

Jones, H., R.A. Leigh, A.D. Tomos, and R.G. Wyn Jones. 1987. The effect of abscisic acid on cell turgor pressures, solute content and growth of wheat roots. Planta 170:257-262. doi:10.1007/BF00397896

Keeling, C.D., and T.P. Whorf. 2005. Atmospheric $\mathrm{CO}_{2}$ records from sites in the SIO air sampling network. In: Trends: A compendium of data on global change. Carbon Dioxide Information Analysis Ctr., Oak Ridge Natl. Lab., U.S. Dep. of Energy, Oak Ridge, TN.

Keith, H., J.M. Oades, and J.K. Martin. 1986. Input of carbon to soil from wheat plants. Soil Biol.Biochem. 18:445-449. doi:10.1016/0038-0717(86)90051-9

Kell, D.B. 2011. Breeding crop plants with deep roots: Their role in sustainable carbon, nutrient and water sequestration. Ann. Bot. (London) 10.1093/aob/ mcr175.

Kimball, B.A. 1983. Carbon dioxide and agricultural yield: An assemblage and analysis of 430 prior observations. Agron.J. 75:779-786. doi:10.2134/agron j1983.00021962007500050014x

Kimball, B.A. 2011. Lessons from FACE: $\mathrm{CO}_{2}$ effects and interactions with water, nitrogen and temperature. In: D. Hillel and C. Rosenzweig, editors, Handbook of climate change and agroecosystems: Impacts, adaptation, and mitigation. Imperial College Press, Hackensack, NJ. p. 87-107.

Kimball, B.A., K. Kobayashi, and M. Bindi. 2002. Responses of agricultural crops to free-air $\mathrm{CO}_{2}$ enrichment. Adv. Agron. 77:293-368. doi:10.1016/ S0065-2113(02)77017-X

King, J.S., K.S. Pregitzer, and D.R. Zak. 1999. Clonal variation in above- and belowground growth responses of Populus tremuloides (Michaux): Influence of soil warming and nutrient availability. Plant Soil 217:119-130. doi:10.1023/A:1004560311563

Klepper, B., H.M. Taylor, M.G. Huck, and E.L. Fiscus. 1973. Water relations and growth of cotton in drying soils. Agron. J. 65:307-310. doi:10.2134/agronj1 973.00021962006500020036x

Kramer, P.J. 1981. Carbon dioxide concentration, photosynthesis, and dry matter production. Bioscience 31:29-33. doi:10.2307/1308175

Krauss, U., and J.W. Deacon. 1994. Root turnover of groundnut (Arachis hypogaea (L.)) in soil tubes. Plant Soil 166:259-270. doi:10.1007/BF00008339

Laforge, F., C. Lussier, Y. Desjardins, and A. Gosselin. 1991. Effect of light intensity and enrichment during in-vitro rooting on subsequent growth of plantlets of strawberry, raspberry and asparagus in acclimatization. Sci. Hortic. (Amsterdam) 47:259-269. doi:10.1016/0304-4238(91)90009-N

Lampurlanés, J.P., C. Angás, and C. Cantero-Martínez. 2001. Root growth, soil water content and yield of barley under different tillage systems on two soils in semiarid conditions. Field Crops Res. 69:27-40. doi:10.1016/ S0378-4290(00)00130-1

Lawlor, D.W., and R.A.C. Mitchell. 1991. The effect of increasing $\mathrm{CO}_{2}$ on crop photosynthesis and production: A review of field studies. Plant Cell Environ. 14:807-818. doi:10.1111/j.1365-3040.1991.tb01444.x

Liljeroth, E., J.A. Van Veen, and H.J. Miller. 1990. Assimilate translocation to the rhizosphere of two wheat lines and subsequent utilization by rhizosphere microorganisms at two soil nitrogen concentrations. Soil Biol. Biochem. 22:1015-1021. doi:10.1016/0038-0717(90)90026-V

Lin, W.C., and J.M. Molnar. 1981. Effects of mist and high intensity supplementary lighting on propagation of selected woody ornamentals. Can. J. Plant Sci. 61:965-969. doi:10.4141/cjps81-142 
Lorenz, K., and R. Lal. 2005. The depth distribution of soil organic carbon in relation to land use and management and the potential of carbon sequestration in subsoil horizons. Adv. Agron. 88:35-66. doi:10.1016/ S0065-2113(05)88002-2

Lotze-Campen, H., and H.J. Schellnhuber. 2009. Climate impacts and adaptation options in agriculture: What we know and what we don't know. J. Verbraucherschutz und Lebensmittelsicherheit. 4:145-150. doi:10.1007/ s00003-009-0473-6

Luxmoore, R.J., E.G. O’Neill, J.M. Ells, and H.H. Rogers. 1986. Nutrient uptake and growth responses of Virginia pine to elevated atmospheric carbon dioxide. J. Environ. Qual. 15:244-251. doi:10.2134/ jeq1986.00472425001500030008x

McGuire, D., J.M. Melillo, and L.A. Joyce. 1995. The role of nitrogen in the response of forest net primary production to elevated atmospheric carbon dioxide. Annu. Rev. Ecol. Syst. 26:473-503. doi:10.1146/annurev. es.26.110195.002353

McMaster, G.S., D.R. LeCain, J.A. Morgan, L. Aiguo, and D.L. Hendrix. 1999. Elevated $\mathrm{CO}_{2}$ Increases wheat CER, leaf and tiller development, and shoot and root growth. J. Agron. Crop Sci. 183:119-128. doi:10.1046/j.1439-037x.1999.00325.x

Milchunas, D.G., and W.K. Lauenroth. 1992. Carbon dynamics and estimates of primary production by harvest, (14)C dilution, and (14)C turnover. Ecology 73:593-607. doi:10.2307/1940765

Milchunas, D.G., W.K. Lauenroth, J.S. Singh, C.V. Dole, and H.W. Hunt. 1985. Root turnover and production by $14 \mathrm{C}$ dilution: Implications of carbon partitioning in plants. Plant Soil 88:353-365. doi:10.1007/BF02197492

Mo, G.D., M.B. Nie, H. Kirkham He, L.K. Ballou, F.W. Caldwell, and E.T. Kanemasu. 1992. Root and shoot weight in a tall grass prairie under elevated carbon dioxide. Environ. Exp. Bot. 32(3):193-201. doi:10.1016/0098-8472(92)90002-J

Mokany, K., R.J. Raison, and A.S. Prokushkin. 2006. Critical analysis of root: Shoot ratios in terrestrial biomes. Glob. Change Biol. 12:84-96. doi:10.1111/j.1365-2486.2005.001043.x

Mulkey, T.J., M.L. Evans, and K.M. Kuzmanoff. 1983. The kinetics of abscisic acid action on root growth and gravitropism. Planta 157:150-157. doi:10.1007/ BF00393649

Nepstad, D.C., C.R. Decarvalho, E.A. Davidson, P.H. Jipp, P.A. Lefebvre, G.H. Negrelros et al. 1994. The role of deep roots in the hydrological and carbon cycles of Amazonian forests and pastures. Nature (London) 372:666-669. doi: $10.1038 / 372666 \mathrm{a} 0$

Newell, R.L., and W.W. Wilhelm. 1987. Conservation tillage and irrigation effects on corn root development. Agron. J. 79:160-165. doi:10.2134/agronj1987.0 $0021962007900010033 x$

Norby, R.J. 1987. Nodulation and nitrogenase activity in nitrogen-fixing woody plants stimulated by $\mathrm{CO}_{2}$ enrichment of the atmosphere. Physiol. Plant. 71:77-82. doi:10.1111/j.1399-3054.1987.tb04620.x

Norby, R.J. 1994. Issues and perspectives for investigating responses to elevated atmospheric carbon dioxide. Plant Soil 165:9-20. doi:10.1007/BF00009958

Norby, R.J., C.A. Gunderson, S.D. Wullschleger, E.G. O’Neill, and M.K. McCracken. 1992. Productivity and compensatory responses of yellow-poplar trees in elevated. Nature (London) 357:322-332. doi:10.1038/357322a0

Norby, R.J., and E.G. O’Neill. 1989. Growth dynamics and water use of seedlings of Quercus alba (L.) in $\mathrm{CO}_{2}$ enriched atmospheres. New Phytol. 111:491500. doi:10.1111/j.1469-8137.1989.tb00712.x

Norby, R.J., E.G. O’Neill, W.G. Hood, and R.J. Luxmoore. 1987. Carbon allocation, root exudation and mycorrhizal colonization of Pinus echinata seedlings grown under $\mathrm{CO}_{2}$ enrichment. Tree Physiol. 3:203-210. doi:10.1093/ treephys/3.3.203

Norby, R.J., E.G. O'Neill, and R.J. Luxmoore. 1986a. Effects of atmospheric $\mathrm{CO}_{2}$ enrichment on the growth and mineral nutrition of Quercus alba seedlings in a nutrient poor soil. Plant Physiol. 82:83-89. doi:10.1104/pp.82.1.83

Norby, R.J., J. Pastor, and J.M. Melillo. 1986b. Carbon nitrogen interactions in $\mathrm{CO}_{2}$-enriched white oak: Physiological and long-term perspectives. Tree Physiol. 2:233-241. doi:10.1093/treephys/2.1-2-3.233

Obrist, D., and J.A. Arnone. 2003. Increasing $\mathrm{CO}_{2}$ accelerates root growth and enhances water acquisition during early stages of development in Larrea tridentate. New Phytol. 159:175-184. doi:10.1046/j.1469-8137.2003.00791.x

Oechel, W.C., and B.R. Strain. 1985. Native species responses to increased atmospheric carbon dioxide concentration. In: B.R. Strain, and J.D. Cure, editors, Direct effects of increasing carbon dioxide on vegetation. DOE/ER-0238. U.S. Dep. of Energy, Washington, DC. p. 117-154.
O’Neill, E.G., R.J. Luxmoore, and R.J. Norby. 1987a. Elevated atmospheric CO, effects on seedling growth, nutrient uptake, and rhizosphere bacterial populations of Liriodendron tulipifera (L.). Plant Soil 104:3-11. doi:10.1007/ BF02370618

O’Neill, E.G., R.J. Luxmoore, and R.J. Norby. 1987b. Increases in mycorrhizal colonization and seedling growth in Pinus echinata and Quercus alba in an enriched $\mathrm{CO}_{2}$ atmosphere. Can. J. For. Res. 17:878-883. doi:10.1139/x87-139

Paustian, K., E.T. Elliot, G.A. Peterson, and K. Killian. 1996. Modeling climate, $\mathrm{CO}_{2}$ and management impacts on soil carbon in semi-arid agro ecosystems. Plant Soil 187:351-365. doi:10.1007/BF00017100

Pendall, E., J.Y. King, A.R. Mosier, J.A. Morgan, and D.S. Milchunas. 2005. Stable isotope constraints on net ecosystem production in elevated $\mathrm{CO}_{2}$ experiments. In: L.B. Flanagan, J.R. Ehleringer, and D.E. Pataki, editors, Stable isotopes and biosphere atmosphere interactions. Elsevier, New York. p. 182-198.

Pilet, P.E., and M. Saugy. 1987. Effect on root growth of endogenous and applied IAA and ABA: A critical reexamination. Plant Physiol. 83:33-38. doi:10.1104/pp.83.1.33

Pilumwong, J., C. Senthong, S. Srichuwong, and K.T. Ingram. 2007. Effects of temperature and elevated $\mathrm{CO}_{2}$ on shoot and root growth of Peanut (Arachis hypogaea (L.)) grown in controlled environment chambers. Sci. Asia 33:7987. doi:10.2306/scienceasia1513-1874.2007.33.079

Pregitzer, K.S., D.R. Zak, P.S. Curtis, M.E. Kubiske, J.A. Teeri, and C.S. Vogel. 1995. Atmospheric $\mathrm{CO}_{2}$, soil nitrogen and turnover of fine roots. New Phytol. 129:579-585. doi:10.1111/j.1469-8137.1995.tb03025.x

Pregitzer, K.S., D.R. Zak, J. Maziasz, J. DeForest, P.S. Curtis, and J. Lussenhop. 2000. Fine-root growth, mortality, and morphology in a factorial elevated atmospheric $\mathrm{CO}_{2}$ soil $\mathrm{N}$ availability experiment. Ecol. Appl. 10:18-33.

Prior, S.A. 1992. Cotton root response to free-air $\mathrm{CO}_{2}$ enrichment. PhD. diss. Auburn Univ., Auburn, AL.

Prior, S.A., H.H. Rogers, G.L. Mullins, and G.B. Runion. 2003. The effects of elevated atmospheric $\mathrm{CO}_{2}$ and soil $\mathrm{P}$ placement on cotton root deployment. Plant Soil 255:179-187. doi:10.1023/A:1026143410238

Prior, S.A., H.H. Rogers, G.B. Runion, and G.R. Hendrey. 1994a. Free-air $\mathrm{CO}_{2}$ enrichment of cotton: Vertical and lateral root distribution patterns. Plant Soil 165:33-44. doi:10.1007/BF00009960

Prior, S.A., H.H. Rogers, G.B. Runion, B.A. Kimball, J.R. Mauney, K.F. Lewin, J. Nagy, and G.R. Hendrey. 1995. Free-air $\mathrm{CO}_{2}$ enrichment of cotton: Root morphological characteristics. J. Environ. Qual. 24:678-683. doi:10.2134/ jeq1995.00472425002400040019x

Prior, S.A., H.H. Rogers, G.B. Runion, and J.R. Mauney. 1994b. Effects of free-air $\mathrm{CO}_{2}$ enrichment on cotton root growth. Agric. For. Meteorol. 70:69-86. doi:10.1016/0168-1923(94)90048-5

Prior, S.A., G.B. Runion, H.H. Rogers, H.A. Torbert, and D.W. Reeves. 2005. Elevated atmospheric $\mathrm{CO}_{2}$ effects on biomass production and soil carbon in conventional and conservation cropping systems. Glob. Change Biol. 11:657-665. doi:10.1111/j.1365-2486.2005.00935.x

Prior, S.A., H.A. Torbert, G.B. Runion, G.L. Mullins, H.H. Rogers, and J.R. Mauney. 1998. Effects of $\mathrm{CO}_{2}$ enrichment on cotton nutrient dynamics. J. Plant Nutr. 21:1407-1426. doi:10.1080/01904169809365492

Pritchard, S.G., and J.S. Amthor. 2005. Crops and environmental change: An introduction to effects of Gglobal warming, increasing atmospheric and $\mathrm{O}_{3}$ concentrations and soil salinization on crop physiology and yield. The Haworth Press, Binghamton, NY.

Pritchard, S.G., S.A. Prior, H.H. Rogers, A. Micheal, G. Davis, B. Runion, and T.W. Popham. 2006. Effects of elevated atmospheric $\mathrm{CO}_{2}$ on root dynamics and productivity of sorghum grown under conventional and conservation agricultural Management practices. Agric. Ecosyst. Environ. 113:175-183. doi:10.1016/j.agee.2005.09.010

Pritchard, S.G., and H.H. Rogers. 2000. Spatial and temporal deployment of crop roots in $\mathrm{CO}_{2}$-enriched environments. New Phytol. 147:55-71. doi:10.1046/j.1469-8137.2000.00678.x

Pritchard, S.G., H.H. Rogers, S.A. Prior, and C.M. Peterson. 1999. Elevated $\mathrm{CO}_{2}$ and plant structure: A review. Glob. Change Biol. 5:807-837. doi:10.1046/j.1365-2486.1999.00268.x

Qin, Z., and Y. Huang. 2010. Quantification of soil organic carbon sequestration potential in cropland: A model approach. Sci. China-Life Sci. 53:868-884. doi:10.1007/s11427-010-4023-3

Rastetter, E.B., G.I. Agren, and G.R. Shaver. 1997. Responses of N limited ecosystems to increased $\mathrm{CO}_{2}$ : A balanced-nutrition, coupled-element-cycles model. Ecol. Appl. 7:444-460.

Reynolds, J.F., and J.H.M. Thornley. 1982. A shoot: Root partitioning model. Ann. Bot. (London) 49:585-597. 
Rillig, M.C., S.F. Wright, M.F. Allen, and C.B. Field. 1999. Rise in carbon dioxide changes soil structure. Nature (London) 400:628. doi:10.1038/23168

Robinson,D.2004.Scalingthedepths:Below-groundallocationinplants,forestsand biomes. Funct. Ecol. 18:290-295. doi:10.1111/j.0269-8463.2004.00849.x

Rogers, H.H., G.E. Bingham, J.D. Cure, J.M. Smith, and K.A. Surano. 1983. Responses of selected plant species to elevated carbon dioxide in the field. J. Environ. Qual. 12:569-574. doi:10.2134/ jeq1983.00472425001200040028x

Rogers, H.H., C.M. Peterson, J.M. McCrimmon, and J.D. Cure. 1992. Response of soybean roots to elevated atmospheric carbon dioxide. Plant Cell Environ. 15:749-752. doi:10.1111/j.1365-3040.1992.tb01018.x

Rogers, H.H., S.A. Prior, and E.G. O’Neill. 1993. Cotton root and rhizosphere responses to free-air $\mathrm{CO}_{2}$ enrichment. In: G.R. Hendrey, editor, Free-air $\mathrm{CO}_{2}$ enrichment for plant research in the field. CRC Press, Boca Raton, FL.

Rogers, H.H., S.A. Prior, G.B. Runion, and R.J. Mitchell. 1996. Root to shoot ratio of crops as influenced by $\mathrm{CO}_{2}$. Plant Soil 187:229-248. doi:10.1007/ BF00017090

Rogers, H.H., G.B. Runion, and S.V. Krupa. 1994. Plants' responses to atmospheric enrichment with emphasis on roots and the rhizosphere. Environ. Pollut. 83:155-189. doi:10.1016/0269-7491(94)90034-5

Rogers, H.H., G.B. Runion, S.V. Krupa, and S.A. Prior. 1997. Plant responses to atmospheric carbon dioxide enrichment: Implications in root-soil-microbe interactions. In: L.H. Allen et al., editors, Advances in carbon dioxide effects research. ASA, Madison, WI. p. 1-34.

Rogers, H.H., G.B. Runion, S.A. Prior, and H.A. Torbert. 1999. Response of plants to elevated atmospheric $\mathrm{CO}_{2}$ : Root growth, mineral nutrition, and soil carbon. In: Y. Luo and H.A. Mooney, editors, Carbon dioxide and environmental stress. Academic Press, San Diego, CA. p. 215-244.

Rose, D.A. 1983. The description of the growth of root systems. Plant Soil 75:405415. doi:10.1007/BF02369974

Roseberg, R.J., and E.L. McCoy. 1992. Tillage and traffic induced changes in macro porosity and macro pore continuity: Air permeability assessment. SoilSci.Soc. Am. J. 56:1261-1267. doi:10.2136/sssaj1992.03615995005600040042x

Salsman, K.J., D.N. Jordan, S.D. Smith, and D.S. Neuman. 1999. Effect of atmospheric enrichment on root growth and carbohydrate allocation of Phaseolus spp. Int. J. Plant Sci. 160:1075-1081.

Sarker, B.C., and M. Hara. 2009. Effects of elevated $\mathrm{CO}_{2}$ and water stress on root structure and hydraulic conductance of Solanum melongena L. Bangladesh J. Bot. 38:55-63.

Schenk, H.J., and R.B. Jackson. 2002a. The global biogeography of roots. Ecol. Monogr. 72:311-328. doi:10.1890/0012-9615(2002)072[0311:TGBOR]2 $.0 . \mathrm{CO} ; 2$

Schenk, H.J., and R.B. Jackson. 2002b. Rooting depths, lateral root spreads and below-ground/above-ground allometries of plants in water-limited ecosystems. J. Ecol. 90:480-494. doi:10.1046/j.1365-2745.2002.00682.x

Smucker, A.J.M. 1993. Soil environmental modifications of root dynamics and measurement. Annu. Rev. Phytopathol. 31:191-216. doi:10.1146/annurev. py.31.090193.001203

Stulen, I., and J. den Hertog. 1993. Root growth and functioning under atmospheric $\mathrm{CO}_{2}$ enrichment. Vegetatio 104-105:99-115. doi:10.1007/ BF00048147

Suter, D., M. Frehner, B.U. Fischer, J. Nösberger, and A. Lüscher. 2002. Elevated $\mathrm{CO}_{2}$ increases carbon allocation to the roots of Lolium perenne under freeair $\mathrm{CO}_{2}$ enrichment but not in a controlled environment. New Phytol. 154:65-75. doi:10.1046/j.1469-8137.2002.00368.x

Swinnen, J., J.A. Van Veen, and R. Merckx. 1994. C pulse-labeling of field grown spring wheat: An evaluation of its use in rhizosphere carbon budget estimations. Soil Biol. Biochem. 26:161-170. doi:10.1016/0038-0717(94)90159-7

Swinnen, J., J.A. Van Veen, and R. Merckx. 1995. Root decay and turnover of rhizodeposits in field-grown winter wheat and spring barley estimated by $14^{\mathrm{C}}$ pulse-labeling. Soil Biol. Biochem. 27:211-217. doi:10.1016/0038-0717(94)00161-S

Vanaja, M., P. Raghuram Reddy, N. Jyothi Lakshmi, M. Maheswari, P. Vagheera, P. Ratnakumar et al. 2007. Effect of elevated atmospheric $\mathrm{CO}_{2}$ concentrations on growth and yield of black gram (Vigna mungo (L.) Hepper) - A rainfed pulse crop. Plant Soil Environ. 53(2):81-88. van der Werf, A., A. Kooijman, R. Welschen, and H. Lambers. 1988. Respiratory energy costs for the maintenance of biomass, for growth and for ion uptake in roots of Carex diandra and Carex acutiformin. Physiol. Plant. 72:483-491. doi:10.1111/j.1399-3054.1988.tb09155.x

van Noordwijk, M., G. Brouwer, H. Koning, F.W. Meijboom, and W. Grzebisz. 1994. Production and decay of structural root material of winter wheat and sugar beet in conventional and integrated cropping systems. Agric. Ecosyst. Environ. 51:99-113. doi:10.1016/0167-8809(94)90037-X

van Noordwijk, M., P. Martikainen, P. Bottner, E. Cuevas, C. Rouland, and S.S. Dhillion. 1998. Global change and root function. Glob. Change Biol.4:759772. doi:10.1046/j.1365-2486.1998.00192.x

Van Veen, J.A., E. Liljeroth, , L.J.A. Lekkerkerk, and S.C. van de Geijn. 1991. Carbon fluxes in plant-soil systems at elevated atmospheric $\mathrm{CO}_{2}$ levels. Ecol. Appl. 1(2):175-181. doi:10.2307/1941810

Van Vuuren, M.M.I., D. Robinson, A.H. Fitter, S.D. Chasalow, L. Williamson, and J.A. Raven. 1997. Effects of elevated atmospheric $\mathrm{CO}_{2}$ and soil water availability on root biomass, root length and $\mathrm{N}, \mathrm{P}$, and $\mathrm{K}$ uptake by wheat. New Phytol. 135:455-466. doi:10.1046/j.1469-8137.1997.00682.x

Walton, D.C., M.A. Harrison, and P. Cote. 1976. The effects of water stress on abscisic acid levels and metabolism in roots of Phaseolus vulgaris and other plants. Planta 131:141-144. doi:10.1007/BF00389985

Wan, S., R.J. Norby, K.S. Pregitzer, J. Ledford, and E.G. O'Neill. 2004. $\mathrm{CO}_{2}$ enrichment and warming of the atmosphere enhance both productivity and mortality of maple tree fine roots. New Phytol. 162:437-446. doi:10.1111/j.1469-8137.2004.01034.x

Wang, Y.G., Y. Li, X.H. Ye, Y. Chu, and X.P. Wang. 2010. Profile storage of organic inorganic carbon in soil: From forest to desert. Sci. Total Environ. 408:1925-1931. doi:10.1016/j.scitotenv.2010.01.015

Warrick, R.A. 1988. Carbon dioxide, climatic change and agriculture. Geogr. J. 154:221-233. doi:10.2307/633848

Watson, C.A., J.M. Ross, U. Bangnaresi, G.F. Minotta, F. Roffi, D. Atkinson et al. 2000. Environmental induced modifications to root longevity in Lolium perenne and Trifolium repens. Ann. Bot. (London) 85:397-401. doi:10.1006/ anbo. 1999.1048

Watts, S., J.L. Rodriguez, S. Evans, and W.J. Davies. 1981. Root and shoot growth of plants treated with abscisic acid. Ann. Bot. (London) 47:595-602.

Wechsung, G. 1999. The effects of free-air CO2 enrichment and soil water availability on spatial and seasonal patterns of wheat root growth. Global Change Biol. 5:519-529.

Wechsung, G., F. Wechsung, G.W. Wall, F.J. Adamsen, B.A. Kimball, R.L. Garcia, P.J. Pinter, Jr., and T. Kartschall. 1995. Biomass and growth rate of a spring wheat root system grown in free-air $\mathrm{CO}_{2}$ enrichment (FACE) and ample moisture. J. Biogeogr. 22:623-634. doi:10.2307/2845963

Wechsung, G., F. Wechsung, G.W. Wall, F.J. Adamsen, B.A. Kimball, P.J. Pinter, Jr., T. Kartschall, R.L. Garcia, and R.L. LaMorte. 1999. The effects of free-air $\mathrm{CO}_{2}$ enrichment and soil water availability on spacial and seasonal patterns of wheat root growth. Glob. Change Biol. 5:519-529. doi:10.1046/j.1365-2486.1999.00243.x

Whipps, J.M. 1984. Environmental factors affecting the loss of carbon from the roots of wheat and barley seedlings. J. Exp. Bot. 35:767-773. doi:10.1093/ $\mathrm{jxb} / 35.6 .767$

Whipps, J.M. 1985. Effect of $\mathrm{CO}_{2}$ concentration on growth, carbon distribution and loss of carbon from the roots of maize. J. Exp. Bot. 36:644-651. doi:10.1093/jxb/36.4.644

Wittwer, S.H. 1978. Carbon dioxide fertilization of crop plants. In: U.S. Gupta, editor, Problems in crop physiology. Haryana Agric. Univ., Hissar, India. p. 310-333.

Wullschleger, S.D., W.M. Post, and A.W. King. 1995. On the potential for a $\mathrm{CO}_{2}$ fertilization effect in forests: Estimates of the biotic growth factor based on 58 controlled-exposure studies. In: A.W. Woodwell and F.T. Mackensie, editors, Biospheric feedbacks in the global climate system: Will warming feed the warming? Oxford Univ. Press, Cambridge, UK. p. 85-107.

Zhang, J., and W.J. Davies. 1987. Increased synthesis of ABA in partially dehydrated root tips and ABA transport from roots to leaves. J. Exp. Bot. 38:2015-2023. doi:10.1093/jxb/38.12.2015

Zhao, X., I.J. Misaghi, and M.C. Hawes. 2000. Stimulation of border cell production in response to increased carbon dioxide levels. Plant Physiol. 122:181188. doi:10.1104/pp.122.1.181 